\title{
Social-ecological trends: managing the vulnerability of coastal fishing communities
}

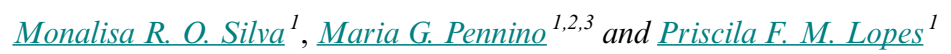

\begin{abstract}
The loss of biodiversity, including the collapse of fish stocks, affects the vulnerability of social-ecological systems (SESs) and threatens local livelihoods. Incorporating community-centered indicators and SES drivers and exposures of change into coastal management can help anticipate and mitigate human and/or coastal vulnerability. We have proposed a new index to measure the socialecological vulnerability of coastal fishing communities (Index of Coastal Vulnerability [ICV]) based on species, ecosystem, and social indicators. The ICV varies from 0 (no vulnerability) to 1 (very high vulnerability) and is composed of 3 components: species vulnerability, i.e., fish biological traits; ecosystem vulnerability, i.e., environmental indicators of ecosystem health; and adaptive capacity, i.e., human ability to cope with changes. We tested the ICV of Brazil's 17 coastal states. The average ICV for the Brazilian coast was 0.77 , and variation was low among states. More than half of the coastal states revealed very high vulnerability $(>0.8)$. The ecosystem vulnerability values were worse than the adaptive capacity and species vulnerability values, and the North and Northeast regions were revealed to be vulnerable hot spots. Additionally, we investigated how the ICV related to specific anthropogenic risks, i.e., fish landing richness, fishery instability, market, coastal extension, and coastal population, and found that states with fewer species landings and higher coastal populations presented higher ICVs. At a time when human impacts are overtaking natural processes, understanding how these impacts lead to coastal vulnerability can help improve conservation policies. For this case study, we suggest both fisheries management measures and restoration of sensitive habitats to protect species and decrease vulnerability. The integrated evaluation developed here could be used as a baseline for coastal monitoring and conservation planning and be applied to coastal regions in which governments evaluate both social and biological aspects.
\end{abstract}

Key Words: Anthropocene; coupled system; ecosystem services; human ecology; resource dependency

\section{INTRODUCTION}

Anthropogenic activities are pushing ecosystems beyond their ability to maintain processes and services that are fundamental to human societies (Ripple et al. 2017, Aswani et al. 2018). Intense consumption of natural resources has threatened and extinguished species and led to the current biodiversity crises (Corlett 2015), thus impacting the provision of ecosystem services (Cardinale et al. 2012). For instance, coral reefs have been rapidly degrading in response to anthropogenic drivers (Hughes et al. 2017), and top predators have become absent or threatened, both at sea and on land (McGill et al. 2015). The current situation of fisheries around the world indicates that the productive capacity of the fish stocks is reaching its limit (Food and Agriculture Organization of the United Nations [FAO] 2016).

Overfishing can cause fluctuations in fish catches (Pomeroy et al. 2016), reduce biodiversity, and affect the provision of marine services (Christensen et al. 2014), which directly threatens food, income, and livelihood security, especially in the developing world (FAO 2012). Depletion of fish stocks also has serious consequences on human livelihoods (Kleisner et al. 2013b, Teh and Sumaila 2013). The sustainability of vital ecosystem services that humans depend on for their livelihoods is crucial to maintaining balanced social-ecological systems (SESs). Although many groups of people in different social-ecological contexts can adapt reasonably well to an environmentally changing world, these adaptations do not necessarily imply better lives. People, such as artisanal fishers for example, who rely heavily on natural resources, have been burdened by multiple changes in the ecosystems, e.g., depletion of fish stocks, that vary according to their own social-ecological context (Berkes et al. 2000, Perry et al. 2010). By knowing how vulnerable a system is and the specific conditions that make it vulnerable, key actions can be developed to minimize the impacts of environmental changes and sustain ecosystem services and livelihoods.

Vulnerability can be defined as the state of susceptibility to damage from multiple stressors (Cinner et al. 2013), or as a condition of a system to cope and adapt to changes caused by these disturbances (Adger 2006, Intergovernmental Panel on Climate Change [IPCC] 2014). Social vulnerability, specifically, can be evaluated through indicators of the factors that influence a community's ability to sustain itself against changes to the SES (Liu et al. 2007). In addition to environmental fluctuations, these communities are exposed to other changes, such as economic, social, demographic, and governance-related changes (Bennet et al. 2015, Khan and Cundill 2019). Governance, specifically, which is defined as a continuous process of negotiation on how to manage ecosystems, is considered to be a critical element to solving the problems identified in fisheries (Basurto et al. 2017, Bennett et al. 2019) and needs to be adaptable given that changes to SESs are inevitable (Bennett and Satterfield 2018). From an ethics perspective, coastal governance contributes to identifying blind spots that are overlooked in some fishing SESs, such as issues related to gender inequality, property rights, and social actors (Basurto et al. 2017).

Many coastal marine systems and their associated SESs still retain outstanding biological features, but changes are expected to increase their vulnerability, as the Anthropocene continues to unfold (Steffen et al. 2011). In an SES, more exposed groups, such as those made more vulnerable because of their gender, age, class,

${ }^{1}$ Fishing Ecology, Management and Economics Group (FEME), Department of Ecology, Federal University of Rio Grande do Norte, Natal, Rio Grande do Norte, Brazil, ${ }^{2}$ Statistical Modeling Ecology Group (SMEG), Departament d'Estadística i Investigació Operativa, Universitat de València, Valencia, Spain, ${ }^{3}$ Instituto Español de Oceanografia (IEO), Centro Oceanográfico de Vigo, Vigo, Pontevedra, Spain 
and/or ethnicity usually feel these changes first (O'Brien et al. 2010). This is true even for groups, such as women, whose contribution to collective action in fisheries is crucial (Di Ciommo and Schiavetti 2012, Alonso-Población and Siar 2018) but who are still subjected to high levels of discrimination (Harper et al. 2013, Siar and Kalikoski 2016). To date, most of the social vulnerability research has focused on the effects of climate change (Dolan and Walker 2004, Cinner et al. 2013). However, vulnerability driven by other factors, such as overfishing, population growth, market fluctuations that impact seafood prices, fisheries technology, infrastructure developments, and governance and policies, should not be disregarded (Bennett et al. 2017).

Given the diverse methods by which fish are caught and the different governance regimes (World Wildlife Fund [WWF] 2016), coastal communities in Brazil serve as an important case study. Although the country has one of the largest coastlines in the world and a huge Exclusive Economic Zone, fish production has declined over the last decades, and some estimates suggest that there are few, if any, unexploited fishing resources that could endure additional harvest (Ruffino and Abdallah 2016). Moreover, the Brazilian coastline has undergone multiple environmental and socioeconomic changes over the last 50 years, which have negatively impacted both fish stocks and local livelihoods (Prates et al. 2012, Reis et al. 2016). Lack of effective governance to promote sustainable fishing in a changing world is an important part of this failure to preserve fish stocks and protect local livelihoods and is possibly the main threat to the Brazilian marine systems (Dias-Neto and Dias 2015, Ruffino and Abdallah 2016).

The need to evaluate the relationships between the social and ecological dimensions of human vulnerability is now urgent (Cinner et al. 2013, Daw et al. 2016) if healthier governance regimes are to be established. It is especially important to consider that changes to SESs occur at different scales and speeds and thus produce different outcomes from one community to the next (IPCC 2014, Bennett et al. 2016). Therefore, it is crucial to understand who and where the vulnerable people and species are, how to reduce their vulnerability, and where the economic consequences of vulnerable fisheries systems will be felt the most.

We used an innovative and integrative approach to explore socialecological vulnerabilities driven by multiple interacting socioeconomic and ecological changes along the Brazilian coast in fishery-dependent communities. Adopting the perspective that humans and the natural environment constantly interact (Liu et al. 2007, Aswani et al. 2018), we constructed an index of coastal vulnerability that is composed of biological and social-related variables and that considers the interactions between the system, pressures, and threats. We first identified which aspects are important to determining coastal vulnerability and then related the index to ecological, demographic, geographic, and socioeconomic indicators. Second, we investigated two hypotheses to explain the vulnerability of coastal communities: (1) whether lower fish richness in landings and stability of fishing resources were associated with high coastal vulnerability; and (2) whether regions with larger coastal extensions, greater populations, and higher market indexes tend to be more vulnerable. Social-ecological approaches to assessing coastal vulnerabilities can identify where to focus attention to mitigate the anthropogenic impacts and improve the sustainability measures of marine resources to avoid further collapses. As part of the test of our index, we also generated an index that ranked the vulnerability of all the Brazilian states. This additional result could encourage policy makers to improve their state's index by implementing public and environmental initiatives directed toward conservation and meeting regional needs. Gaining new insights into marine SESs using interdisciplinary modeling approaches will better prepare us to manage marine resources in the Anthropocene.

\section{MATERIAL AND METHODS}

\section{A brief review of vulnerability assessments}

Marine SESs face different types of stressors at different scales and speeds, such as climatic, socio-cultural, economic, and governance (Millenium Ecosystem Assessment 2005, Bennett et al. 2016). Understanding the systems' vulnerabilities is an important step to design means for the SESs to deal with such stressors. However, vulnerability is neither easily defined nor measured (Comte et al. 2019). We specifically adopted the definition that vulnerability corresponds to how natural resources, resource users, and the governance systems are linked and respond to changes (Berkes and Folke 1998, Gunderson 2010).

Consideration of different perspectives, scales, indicators, and the interactions between ecological and human dimensions is crucial to capturing changes in the SES. For this reason, we envisioned the SES to be a single and coupled system where social and ecological components interact closely (Marshall et al. 2013, López-Angarita et al. 2014). Additionally, to date most approaches to dealing with coastal vulnerability have considered the ongoing and expected impacts of climate change (Beck 2014, Lee et al. 2018) and overlooked other harmful structural and systemic factors driving vulnerability (Hinkel 2011, Tschakert et al. 2013). To partially avoid this shortcoming, we used overfishing as a crucial environmental factor that is both affected by and affects the environment, food security, and livelihoods and is capable of triggering regime shifts in SESs. We also used various easy-to-collect indicators that encompass assorted socialecological variables, such as biophysical, social, economic, and governance-related ones, for rapid vulnerability assessments. This is different from most approaches that use a large and/or oversimplified range of indicators (Aswani et al. 2019, Comte et al. 2019).

Finally, given that one of the objectives of conducting vulnerability assessments is to inform policy and decision makers, especially because vulnerability is context specific (O'Brien et al. 2007), we adopted a local-level approach (Hinkel 2011). At the local level, the chances of having enough data on the ecology of species and on the synergism of interactions between humans and the environment are also higher, and, therefore, there is less room for misrepresentation of the system's vulnerability (Tschakert et al. 2013, Khan and Cundill 2019). Our intention is to determine how to most effectively support and enable local and regional efforts to conserve coastal areas and sustainably manage the provision of fisheries ecosystem services. To emphasize the novelty of the proposed approach, we reviewed and compared the existent vulnerability approaches to ours (Table 1). 
Table 1. Comparison of different approaches used in marine hot spot countries. Information regarding the framework used, indicators, spatial scale, geographic area, and other determinants in the vulnerability assessments. FS, food security; IPCC, Intergovernmental Panel on Climate Change; LVI, Livelihood Vulnerability Index.

\begin{tabular}{|c|c|c|c|c|c|}
\hline Study & Approach & Context & Spatial Level & Main Focus of Indicators & Regime Shift \\
\hline $\begin{array}{l}\text { Allison et al. } \\
(2009)\end{array}$ & IPCC (2001) & Climate change & Global & $\begin{array}{l}\text { Socioeconomic dimension of } \\
\text { vulnerability }\end{array}$ & $\begin{array}{l}\text { Declining fish stocks from } \\
\text { climate change }\end{array}$ \\
\hline $\begin{array}{l}\text { Hughes et al. } \\
(2012)\end{array}$ & Adger (2006) & Food security & Global & $\begin{array}{l}\text { Ecological and socioeconomic } \\
\text { dimensions of vulnerability }\end{array}$ & $\begin{array}{l}\text { Declining coral reefs } \\
\text { resources from different } \\
\text { drivers }\end{array}$ \\
\hline $\begin{array}{l}\text { Mamauag et al. } \\
(2013)\end{array}$ & IPCC (2001) & Climate change & Regional & $\begin{array}{l}\text { Ecological and socioeconomic } \\
\text { dimensions of vulnerability }\end{array}$ & $\begin{array}{l}\text { Shifting in coral reef from } \\
\text { climate change }\end{array}$ \\
\hline $\begin{array}{l}\text { Orencio and Fujii } \\
\text { (2013) }\end{array}$ & Buckle et al. (2001) & $\begin{array}{l}\text { Food security/ } \\
\text { livelihood }\end{array}$ & Regional & $\begin{array}{l}\text { Socioeconomic dimensions of } \\
\text { vulnerability, specifically adaptive } \\
\text { capacity }\end{array}$ & $\begin{array}{l}\text { Declining fish stocks from } \\
\text { socioeconomic drivers }\end{array}$ \\
\hline Beck (2014) & $\operatorname{IPCC}(2012)$ & Climate change & Global & $\begin{array}{l}\text { Socioeconomic dimensions of } \\
\text { vulnerability, specifically on exposure } \\
\text { and adaptive capacity }\end{array}$ & $\begin{array}{l}\text { Climate-driven changes in } \\
\text { the coastal areas }\end{array}$ \\
\hline $\begin{array}{l}\text { Metfcalf et al. } \\
(2015)\end{array}$ & $\operatorname{IPCC}(2001) / \mathrm{LVI}^{\dagger}$ & Climate change & National & $\begin{array}{l}\text { Socioeconomic dimension of } \\
\text { vulnerability }\end{array}$ & $\begin{array}{l}\text { Shifting socioeconomic } \\
\text { activities in coastal } \\
\text { communities }\end{array}$ \\
\hline Lee et al. (2018) & $\begin{array}{l}\text { IPCC (2001), Adger } \\
(2006) \text {, and } \\
\text { Lovelock et al. } \\
(2015)\end{array}$ & Climate change & National & $\begin{array}{l}\text { Ecological dimension of } \\
\text { vulnerability, specifically biophysical } \\
\text { processes }\end{array}$ & $\begin{array}{l}\text { Loss of primary } \\
\text { productivity in mangrove }\end{array}$ \\
\hline $\begin{array}{l}\text { Aswani et al. } \\
(2018)\end{array}$ & $\begin{array}{l}\text { IPCC }(2001) / \mathrm{FS}^{\dagger} / \\
\text { LVI }\end{array}$ & Food security & Global & Social dimension of vulnerability & $\begin{array}{l}\text { Climate-driven changes in } \\
\text { the marine environment }\end{array}$ \\
\hline
\end{tabular}

\section{Measuring coastal vulnerability}

The proposed index, the Index of Coastal Vulnerability (ICV), focuses on the characteristics of fishers, communities, fishing sectors, governance, and ecosystems to estimate their susceptibility to harm (loss or decreased fisheries) at the local level (Fig. 1). This is the level where impacts are mostly felt; therefore, it is the most suited to carry out vulnerability assessments (Hinkel 2011).

We assessed vulnerability by breaking it into three attributes known to affect it: exposure, sensitivity, and adaptive capacity (Adger 2006, Cinner et al. 2013). The combination of exposure and sensitivity represents the potential harm from a given environmental change, and adaptive capacity is determined by the ability to cope with this change through learning (Adger 2006, Bennett et al. 2016). Based on these concepts and the equation proposed by Adger (2006), which includes these three attributes, we created a new equation that simplified the theory behind them. Additionally, we selected our variables by considering both vulnerability and harm indicator concepts: the first one indicates the possibility of being harmed, and the others evaluate the current or future states (good or bad) of a system (Hinkel 2011; Fig. 1).

Given that the ICV was focused on the sustainable provision of fisheries ecosystem services, the vulnerability assessment encompassed three components of SESs: species vulnerability (SP), ecosystem vulnerability (ECO), and adaptive capacity of coastal communities (AC). Each component was formed by different indicators and variables (to be described in the next section) that varied from 0 to 4 (AC component), 0 to 8 (SP component), and 0 to 5 (ECO component). An equal weighting approach was used to weigh components as it was assumed that each component is equally important to coastal vulnerability.

However, given that our decisions in the process of weighting the indicators could be unclear, we ran a sensitivity analysis to improve transparency in the construction of the composite index and to check the robustness of our findings. In addition to the equal weight approach, we tested three other weighting schemes to check how each component contributed to estimating the index values. To do so, we calculated the index by emphasizing one dimension at a time and assigning a $1 / 2$ to the emphasized component and 1/4 to the other two. For example, in the first test, the AC component receives a 1/2 weight, whereas SP and ECO would receive a $1 / 4$ weight each. In the next round, a different component would receive a $1 / 2$ weight and so on. Although each of these weighting approaches affected the index values, the final ranking of coastal states was very similar across them (Appendix 1). Furthermore, from a social-ecological perspective, social and ecological parts of a system are equally important, thus further supporting the adopted equal weighting approach. Finally, the weighting approach we used has been applied in other composite indexes in environmental contexts (Swanson et al. 2009, MorenoSánchez and Maldonado 2013).

To build the ICV, all variables were turned into quantitative data, and each component was normalized to vary from 0 to 1 . We considered the median of each component to calculate the ICV value. A higher AC implies lower vulnerability; therefore, the lower the index value, the lower the system's vulnerability. The final value of the ICV was determined as follows:

$$
\mathrm{ICV}=(\mathrm{SP}+\mathrm{ECO})-\mathrm{AC}
$$


Fig. 1. (A) Conceptual model of vulnerability (V): the state of susceptibility to harm is the system's vulnerability, which is determined by exposure (E), sensitivity (S), and adaptive capacity (AC) attributes (Adger 2006), and where V = (E + S) - AC. (B) Conceptual framework of coastal vulnerability nested in the social-ecological fishing system, which presents the interaction between fishing communities and marine ecosystems. Following this framework, variables were created to estimate the system's susceptibility to be harmed and to capture its vulnerability to social and/or environmental changes at the local/regional scale. SES, socialecological system.
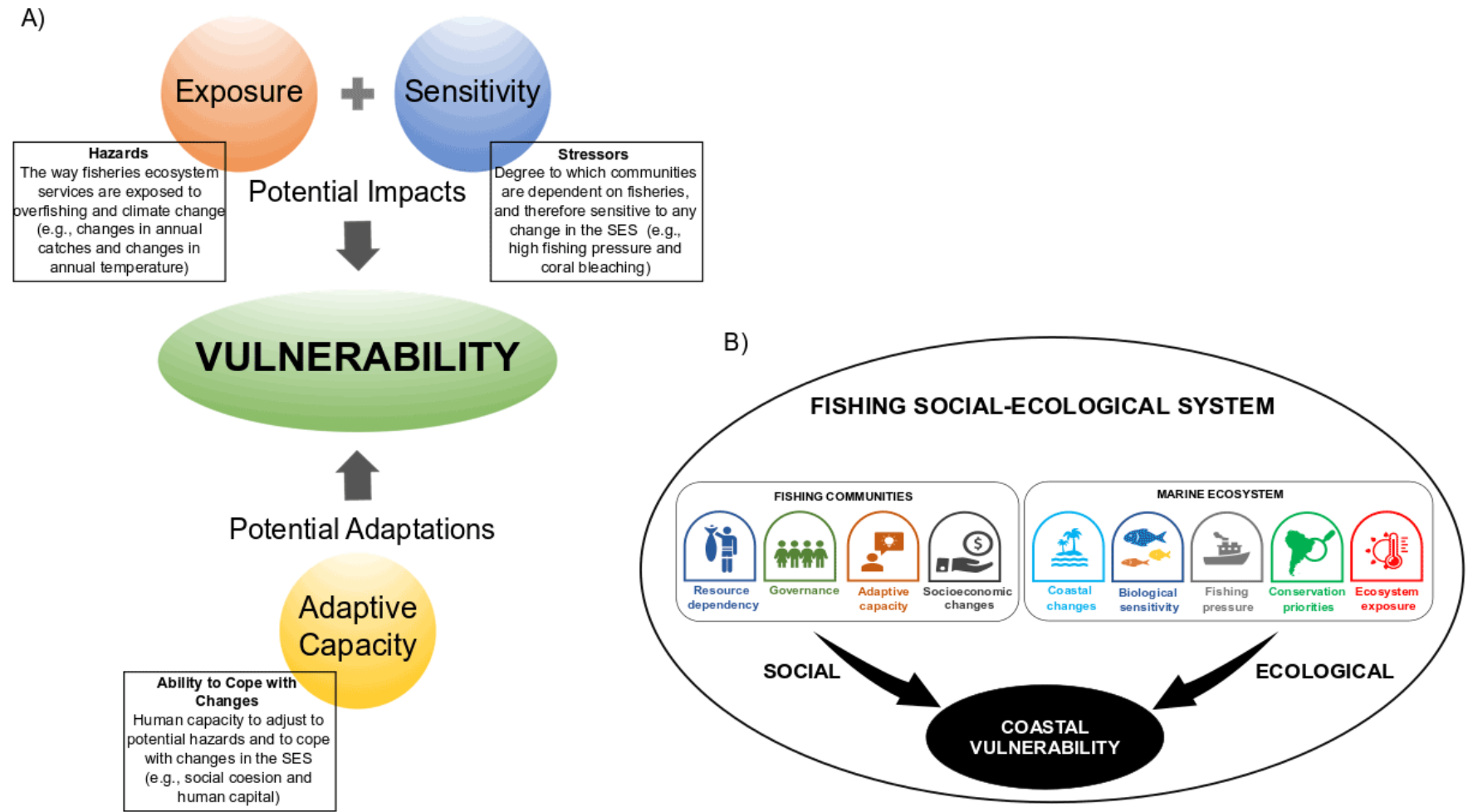

We calculated the ICV for each state along the Brazilian coastline ( $\mathrm{N}=17$; Fig. 2). The ICV value varied from 0 to 2 points, i.e., the sum of maximum scores for SP and ECO components. However, we also rescaled the final values to range from 0 to 1 . The total points were then assigned to a qualitative scale with 5 levels, ranging from least vulnerable (very low) to most vulnerable (very high), and each state was categorized according to its final index value (the categories were arbitrarily defined): very low ( 0 to 0.20$)$, low $(0.21$ to 0.40$)$, moderate $(0.41$ to 0.60$)$, high $(0.61$ to 0.80$)$, and very high $(0.81$ to 1.00$)$. To better examine the results, we created sensitivity maps from these categories for each component and for the final value of the coastal vulnerability index: AC (green sale), SP (orange scale), ECO (blue scale), and ICV (red scale).

Thus, the index was designed by combining information from different sources with feasible and low-cost variables. Moreover, the index is easily replicable by nonexperts and provides a quick and general overview of large geographic areas without exhaustive and expensive data collection, thus enabling policy makers to better anticipate future regime shifts.

\section{Assessing adaptive capacity}

Adaptive capacity (AC), which is defined by the ability of households to anticipate and respond to changes and to minimize, cope with, and recover from the consequences of such changes (McClanahan et al. 2008), was included in the equation as it contributes to decreasing vulnerability (Béné et al. 2016). It can be estimated by social and human capital, ability to learn, and governance aspects of a given society (Adger 2003, Lebel et al. 2006). Social capital, e.g., social cohesion, specifically, contributes to decreasing vulnerability because it can create an appropriate social environment to sustain the changes and unlock the capacities of communities to adapt to changes (Adger 2003, Béné et al. 2016). Human capital, such as livelihood resources or human conditions, is an important contributor to community resilience (McClanahan et al. 2008). The ability to learn refers to how communities can learn from environmental disturbances and social-environmental actions that occur in their area (Marshall and Marshall 2007). Social or environmental changes may teach people how to behave when facing future disturbances; hence, communities that can learn from such changes tend to be more resilient. Governance, e.g., structures and processes used by societies to share power and collective actions, can be expressed through norms of interaction, which shape the contexts in which human groups challenge decisions and determine access to resources (Lebel et al. 2006). Good governance regimes have attributes that can improve the fit between knowledge, action, and social-ecological contexts, thereby allowing societies to better respond to changes (Lebel et al. 2006).

Although it is important to recognize that coastal populations are not homogeneous (Khan et al. 2018), and that existing groups, e.g., minority groups and different social classes, are not equally 
Fig. 2. Study area encompassing 17 coastal states distributed over 5 marine ecoregions, according to the ecoregions proposed by Spalding et al. (2007), along the Brazilian coastline (ecoregions presented from north to south). State fisheries sectors are identified on the map.
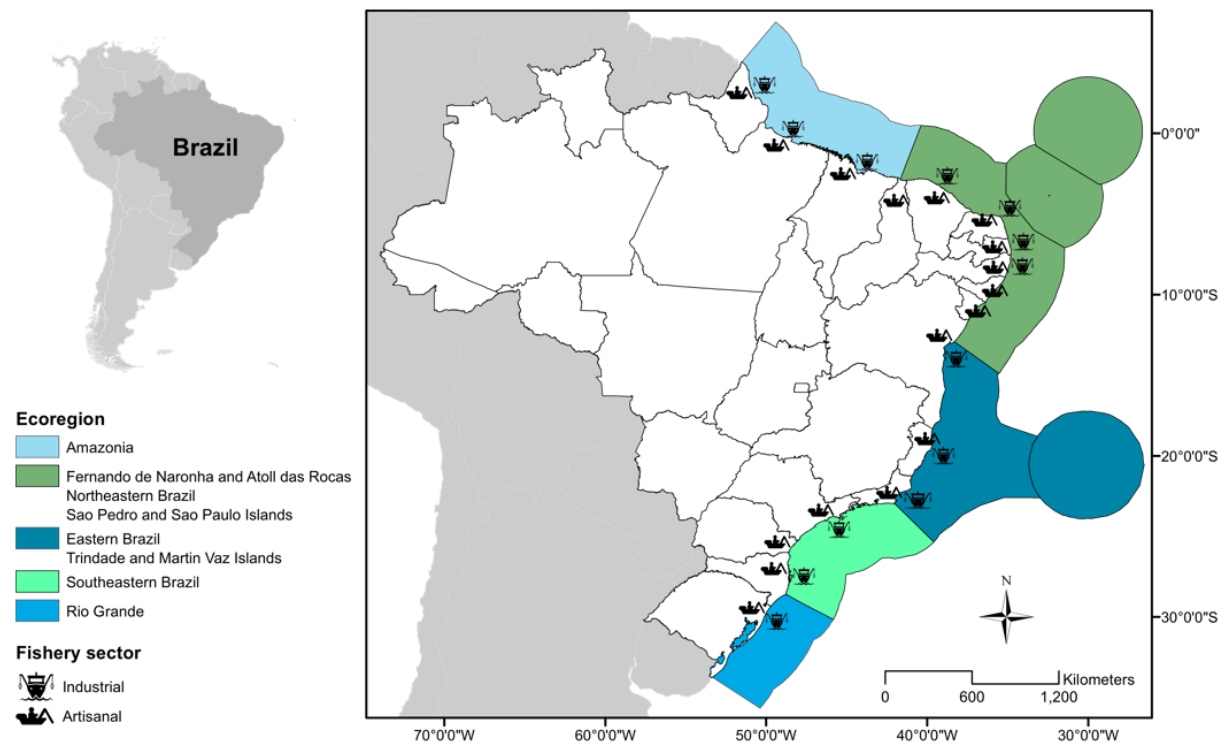

vulnerable when faced with changes (Cinner et al. 2015), we do not have this type of social data to analyze how equity and justice influence the distribution of impacts. For instance, the inclusion of women in fisheries and fisheries governance can reduce their vulnerability and improve their livelihoods (Alonso-Población and Siar 2018). Knowing this could improve actions to deal with uneven vulnerability. However, studies examining gender inequalities in fisheries remain incipient in Brazil.

The specific measures of adaptive capacity we used were the human development index, a proxy for social and human capital; educational attainment, a proxy for ability to learn; presence of an environmental council with solid environmental laws and investment in environmental actions, a proxy for governance; and presence of social and fishery organizations, a proxy for social capital, to assess the ability of human groups to cope with changes and sustain resource users and local institutions (Table 2).

\section{Assessing species vulnerability}

The species vulnerability (SP) dimension includes biological and ecological information on the fish stocks used by artisanal and industrial sectors in the coastal region. For each state, we used landing data and selected the 10 target species with the most recorded landings (in weight) considering both the industrial and artisanal sectors together. In 4 states, the species targeted exclusively by the artisanal sector comprised the bulk of the 10 most abundantly landed species (Fig. 2). We collected biological information on these fish using the information already provided by FishBase: resilience, vulnerability, price category, threat category, trophic level, and distribution range (Froese and Pauly 2017). We also considered the fishing pressure, whether species were caught by 1 or 2 sectors, and the status of the fish stocks (Appendix 2). We did not consider the size or mobility of the fleet. We used the average scores for the 10 fish in each of the indicators that form the species vulnerability component. These indicators represent a proxy for biodiversity security because they capture fish species exposure, ecological vulnerability, and distribution aspects (Table 2).

Assessing ecosystem vulnerability

Communities, such as coastal communities, that depend directly on natural resources, are highly vulnerable to the effects of mismanagement, climate change, overfishing, and environmental degradation, which can negatively impact social-ecological vulnerability (Metcalf et al. 2015). We estimated some environmental indicators of marine ecosystems that can influence fisheries. Ecological studies predict that biological impoverishment will increase in the future, which will eventually threaten fisheries (Cardinale et al. 2012) and affect ecosystem health (Béné et al. 2017). Moreover, ecosystem health is a growing concern, especially around densely populated coastal areas where hot spots have been identified (Heileman 2009). We used estimates of primary productivity, level of marine protection, coastal pollution, climate exposure, and the percentage of conservation priority areas as input indicators to determine ecosystem vulnerability (ECO; Table 2).

\section{Coastal social-ecological systems in Brazil}

To test the ICV, we considered the SESs of fishing communities located along the coast of Brazil, an area covering $8500 \mathrm{~km}$ along the western Atlantic, together with their marine environment, including their fishing area in the exclusive economic zone (3.5 million $\mathrm{km}^{2}$ ). The regional level adopted was based on the political state scope needed to help implement coastal management policies in the future. Brazil has 17 coastal states distributed across 4 regions: North, Northeast, Southeast, and South. For most of them (11), the state capital is located near the coast.

We also discuss the data in terms of the marine ecoregions they represent, following the ecoregion definition of Spalding et al. (2007). Specifically, these 17 states are distributed over 5 marine 
Table 2. Design of the Index of Coastal Vulnerability (ICV). Components and their indicators, description of each variable, score calculation, and source of variables are detailed. ICV is the sum of species vulnerability and ecosystem vulnerability components minus the adaptive capacity of the coastal states. IBGE, Brazilian Institute of Geography and Statistics.

\begin{tabular}{|c|c|c|c|c|}
\hline Components & $\begin{array}{l}\text { Indicators } \\
(0 \text { to } 1)\end{array}$ & Description & Scores & Source of Variables \\
\hline \multirow[t]{4}{*}{$\begin{array}{l}\text { Adaptive } \\
\text { capacity }\end{array}$} & $\begin{array}{l}\text { Human } \\
\text { development index }\end{array}$ & $\begin{array}{l}\text { Human development index as a proxy for } \\
\text { human well-being. Values are from } 2010 \\
\text { (IBGE 2011). It ranges from } 0 \text { to } 1 \text {, i.e., } \\
\text { the closer to } 1 \text {, the greater the human } \\
\text { development. }\end{array}$ & $\begin{array}{l}\text { Range from } 0 \text { to } 1 \text {. The closer to } 1 \text {, the } \\
\text { lower the coastal vulnerability, and vice } \\
\text { versa. }\end{array}$ & http://www.ibge.gov.br \\
\hline & $\begin{array}{l}\text { Educational } \\
\text { attainment }\end{array}$ & $\begin{array}{l}\text { A proxy for human capital that was } \\
\text { measured by the illiteracy rate of each } \\
\text { state, compared with the regional and } \\
\text { national rates (IBGE 2011). }\end{array}$ & $\begin{array}{l}\text { State educational attainment }<\text { regional } \\
\text { average }=0.3 \text { points; state educational } \\
\text { attainment }>\text { regional average or national } \\
\text { average }=0.6 \text { points; state educational } \\
\text { attainment }>\text { regional average and }> \\
\text { national average }=1 \text { point. }\end{array}$ & http://www.ibge.gov.br \\
\hline & Governance & $\begin{array}{l}\text { Estimated by a combination of three } \\
\text { indicators: (1) proportion of } \\
\text { municipalities with environmental laws, (2) } \\
\text { proportion of municipalities with active } \\
\text { environmental councils, and (3) } \\
\text { proportion of municipalities with local } \\
\text { investments in environmental actions. }\end{array}$ & $\begin{array}{l}\text { For all indicators: } \leq 30 \%=0.3 \text { points, } \\
\text { between } 31 \% \text { and } 60 \%=0.6 \text { points, and }> \\
60 \%=1 \text { point. The governance value was } \\
\text { the average of the } 3 \text { indicators. }\end{array}$ & http://www.ibge.gov.br \\
\hline & Social capital & $\begin{array}{l}\text { Presence of social and fisheries } \\
\text { organizations in coastal municipalities, by } \\
\text { state. }\end{array}$ & $\begin{array}{l}\text { More than } 50 \% \text { of municipalities have } \\
\text { social organizations and }>50 \% \text { of } \\
\text { municipalities have fisheries organizations } \\
=1 \text { point; }>50 \% \text { of municipalities have } \\
\text { social organizations, but }<50 \% \text { of } \\
\text { municipalities have fisheries organizations } \\
=0.3 \text { points. }\end{array}$ & $\begin{array}{l}\underline{\mathrm{http}: / / m a p a o s c . i p e a . g o v} . \\
\underline{\mathrm{br}}\end{array}$ \\
\hline \multirow[t]{8}{*}{$\begin{array}{l}\text { Species } \\
\text { vulnerability }^{\dagger}\end{array}$} & Resilience & Resilience of fish species caught. & $\begin{array}{l}\text { Low }=1 \text { point } ; \text { medium }=0.5 \text { points } \text { high } \\
=0 \text { points }\end{array}$ & http://www.fishbase.org \\
\hline & Vulnerability & Vulnerability of fish species caught. & $\begin{array}{l}\text { Low }=0 \text { points } ; \text { medium }=0.5 \text { points; } \\
\text { very high } / \text { high }=1 \text { point. }\end{array}$ & http://www.fishbase.org \\
\hline & Price category & $\begin{array}{l}\text { Price category of target species in the } \\
\text { coastal states. }\end{array}$ & $\begin{array}{l}\text { Low }=0 \text { points } ; \text { medium }=0.5 \text { points; } \\
\text { high }=1 \text { point }\end{array}$ & $\underline{\mathrm{http}: / / w w w . f i s h b a s e . o r g}$ \\
\hline & Threat level & Threat level of fish species caught. & $\begin{array}{l}\text { Critical endangered/endangered/ } \\
\text { vulnerable }=1 \text { point; } \text { near threatened = } \\
0.5 \text { points; not threatened } / \text { least concern } / \\
\text { data deficient }=0 \text { points. }\end{array}$ & $\begin{array}{l}\text { http://www.fishbase.org; } \\
\underline{\text { http://www.mma.gov.br }}\end{array}$ \\
\hline & Trophic level & Trophic level of fish species caught. & $\begin{array}{l}\text { Very high }(\mathrm{TL}>4)=1 \text { point; high }(3.5< \\
\mathrm{TL}<4)=0.8 \text { points; medium }(3<\mathrm{TL}< \\
3.5)=0.4 \text { points; low }(\mathrm{TL}<3)=0 \text { points. }\end{array}$ & http://www.fishbase.org \\
\hline & Distribution range & $\begin{array}{l}\text { Either the number of oceans or the areas } \\
\text { of them where the fish stocks are } \\
\text { distributed. For instance: western } \\
\text { Atlantic, only } 1 \text { area of the Atlantic ocean } \\
\text { (low); western and eastern Atlantic, } 2 \\
\text { areas of the Atlantic ocean (medium); and } \\
\text { Atlantic and Indian oceans, } 2 \text { oceans } \\
\text { (high). This variable can be adapted for } \\
\text { other species distributions around the } \\
\text { world, but it should follow the logic of the } \\
3 \text { categories. }\end{array}$ & $\begin{array}{l}\text { High }=0 \text { points; } \text { medium }=0.5 \text { points; low } \\
=1 \text { point. }\end{array}$ & $\underline{\text { http://www.fishbase.org }}$ \\
\hline & Fishing pressure & $\begin{array}{l}\text { Whether the fish stock is caught by only } 1 \\
\text { sector or by both sectors (artisanal and } \\
\text { industrial). }\end{array}$ & $\begin{array}{l}\text { Only artisanal }=0.3 \text { points; Only } \\
\text { industrial }=0.6 \text { points; Both sectors }=1 \\
\text { point. }\end{array}$ & $\begin{array}{l}\text { http://www.seaaroundus. } \\
\text { org }\end{array}$ \\
\hline & Stock status & $\begin{array}{l}\text { Stock status assessment of the } 10 \text { fish } \\
\text { species caught by artisanal and industrial } \\
\text { sectors. This calculation followed Kleisner } \\
\text { et al. }(2013 a) \text { and used the categories most } \\
\text { frequently observed over the last } 10 \text { years } \\
\text { of the temporal series. }\end{array}$ & $\begin{array}{l}\text { Status: developing }=0 \text { points, exploited }= \\
0.4 \text { points, rebuilding }=0.5 \text { points, } \\
\text { overexploited }=0.8 \text { points, and collapsed } \\
=1 \text { point. }\end{array}$ & $\begin{array}{l}\text { http://www.seaaroundus. } \\
\text { org }\end{array}$ \\
\hline
\end{tabular}




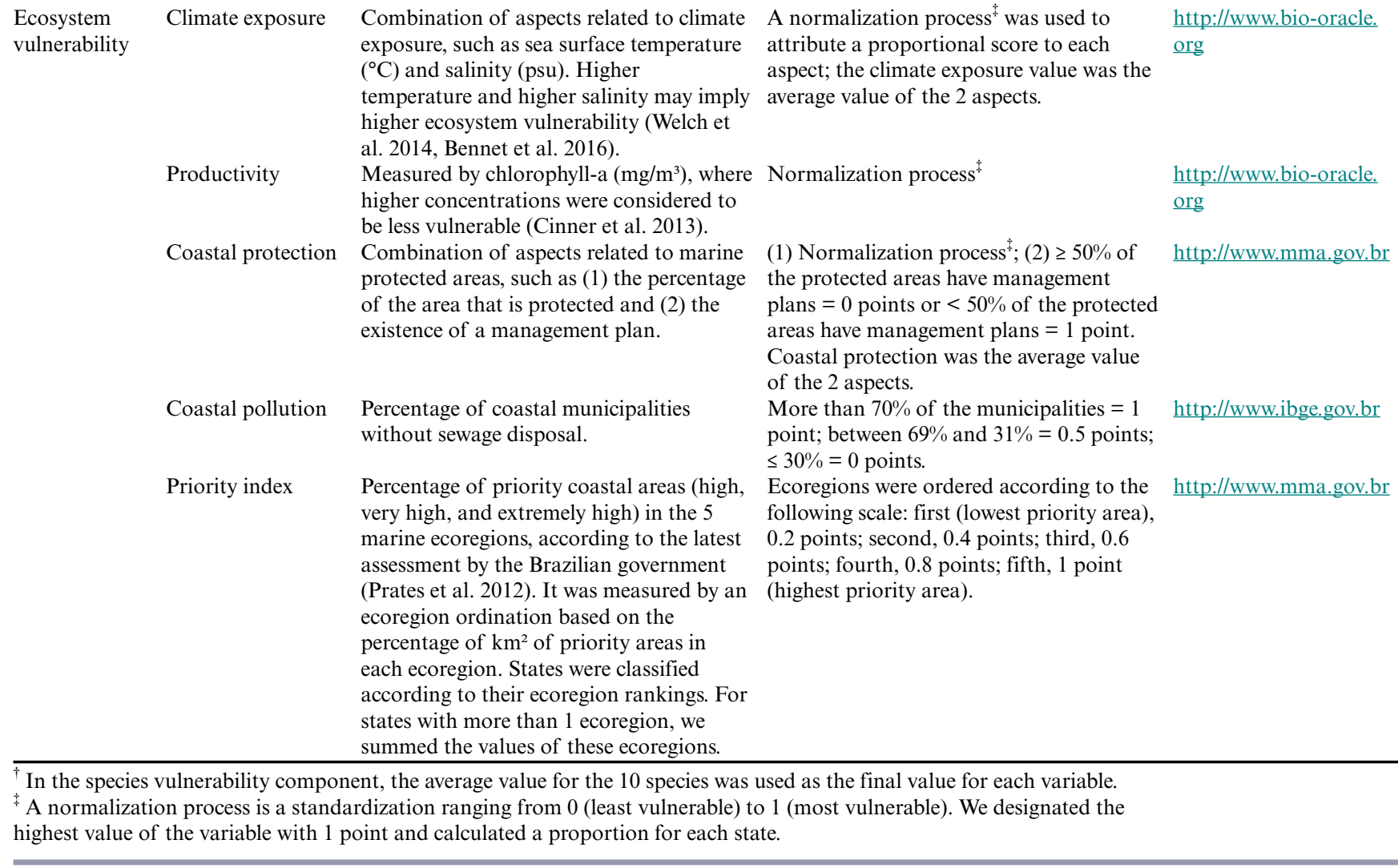

ecoregions: Amazonia; Northeastern Brazil, including Fernando de Noronha/Atoll das Rocas/Sao Pedro and Sao Paulo Islands; Eastern Brazil, including Trindade and Martin Vaz Islands; Southeastern Brazil; and Rio Grande (Fig. 2).

The Brazilian coast encompasses a vast diversity of ecosystems, including mangroves, coral and rocky reefs, lagoons, and estuaries (Prates et al. 2012). These ecosystems provide a variety of marine resources and benefits that play an important role in the Brazilian economy (Elfes et al. 2014), such as those resulting from coastal and oceanic fisheries.

The Northeast region is the quantitatively most important as it produces more than $36 \%$ of total catches in the country, and this total is mainly because of artisanal fishing (WWF 2016). The South region is the second most productive, followed by the Southeast and North regions (WWF 2016). The industrial fishing sector is present mainly in the South and Southeast states (DiasNeto and Dias 2015). Considering the most recent and reliable estimates of fish production per state in Brazil, the states of Santa Catarina (South), Pará (North), Bahia (Northeast), Rio de Janeiro (Southeast), Maranhão (Northeast), São Paulo (Southeast), Rio Grande do Norte (Northeast), and Ceará (Northeast) are the most productive (Dias-Neto and Dias 2015). The total fishing fleet is roughly 65,400 vessels and is formed mostly by small boats, e.g., rowboats, sailboats, or small motorized boats, used mainly by the artisanal fishers in the Northeast region (Dias-Neto and Dias 2015). The industrial and artisanal fishing sector catches increased from an estimated average of $190,000 \mathrm{t} / \mathrm{yr}$ in the early $1950 \mathrm{~s}$ to about $840,000 \mathrm{t} / \mathrm{yr}$ in the late 2000s (Freire et al. 2014, 2015). Such an increase has put most Brazilian marine fish stocks under intense exploitation or in a situation of overfishing (Ruffino and Abdallah 2016, WWF 2016).

In general, fishing is carried out using gill nets, bottom trawling, fish and crustacean bottom traps, longlines, and hook and lines. Artisanal fisheries target reef and coastal fish, e.g., groupers and snappers, such as species from the genera Epinephelus and Lutjanus; whereas industrial fisheries target small and large pelagics, e.g., sardines and albacores, such as species from the genera Sardinella and Thunnus (Dias-Neto and Dias 2015, Freire et al. 2014, 2015). It is estimated that fisheries in Brazil employ more than 1 million fishers, with $41 \%$ represented by women (Ministério da Pesca e Aquicultura 2013), although these data are controversial because of low credibility. The majority of fishers $(84 \%)$ are concentrated in the North and Northeast regions, led by Pará (24\%), Maranhão (17\%), and Bahia (12\%; Ministério da Pesca e Aquicultura 2013). If we include everyone along the fishing value chain, the number of people involved in the fishing sector can reach up to 3.5 million people (Dias-Neto and Dias 2015). Moreover, there are 2081 registered fishery associations in the country (Lopez 2018).

Pollution, overfishing, and socioeconomic changes, e.g., urbanization and tourism, are the main drivers of changes to coastal SESs in Brazil (Ministério do Meio Ambiente [MMA] 2011). In general, Brazilian fisheries management is inadequate and incapable of promoting sustainability for fishing SESs (DiasNeto 2010, WWF 2016). Some initiatives, such as comanagement, 
have been helping decrease pressure on these systems (Kalikoski et al. 2009). However, lack of regulations, enforcement, and engagement of fishers to maintain fisheries in the long term creates a gap of information and increases exploitation rates and the risk of species extinction. Furthermore, the increased degradation and environmental changes to marine ecosystems have affected their ability to provide marine ecosystem services.

\section{Data sources}

We assessed fish stock characteristics, e.g., stock status and species biological traits; ecosystem indicators, e.g., biotic and abiotic variables; and social aspects, e.g., socioeconomic, demographic, and governance factors, in the 17 coastal states (Table 2). The information used to build all indicators was extracted from the most recent data sets available online: the Brazilian Institute of Geography and Statistics (IBGE; http://www.ibge.gov.br), the Institute for Applied Economic Research (IPEA; http://mapaosc. ipea.gov.br), the Brazilian Ministry of the Environment (MMA; http://mma.gov.br), Oracle data set (Bio-ORACLE; http://www. bio-oracle.org/), and FishBase (http://fishbase.org).

Industrial and artisanal fisheries landing data were extracted from the Sea Around Us database, which is a temporal series that spans from 1950 to 2010 (Freire et al. 2015). Abiotic variables, e.g., sea surface temperature, salinity, and chlorophyll-a, were extracted from the Bio-ORACLE database, comprising data from 2005 to 2010 (http://www.bio-oracle.org; Tyberghein et al. 2012, Assis et al. 2018). Fish species information was extracted for 2017 from the FishBase database (Froese and Pauly 2017). Social aspects were extracted from the demographic census data set from 2010 (IBGE 2011) and from the latest update of the civil society organizations registered by the government in 2015 (IPEA 2017). Information about marine protected areas (MPAs) was aggregated using national data published by the Brazilian government in 2012 (Prates et al. 2012).

\section{Data analyses}

We used a Bayesian generalized linear model (BGLM) to analyze the influence of five independent variables on the states' ICV (dependent variable), namely, fish landing richness, fisheries instability indicator, market indicator, coastal extension, and coastal population. Richness was calculated for the period 2001 to 2010 because the data used for the construction of the ICV were from this period. The fisheries instability indicator refers to the tendency of fisheries provision to either remain stable in the face of some perturbation or rapidly return to preperturbation levels (Appendix 3). Per capita fish consumption (kilograms per inhabitant per year) and urban access (linear distance between landing port and state capital) were combined to form a market indicator that attempts to capture fisheries market demand in the coastal states (Appendix 4). To account for the possibility that coastal extension could intensify the degree of anthropogenic changes and economic development and lead to increasing pressure on local ecosystems, we used the coastal extension of each state, measured in kilometers. We examined whether coastal population was affecting ICV because previous studies have suggested that this is an important predictor of fish assemblage structure in rocky shores (Teixeira-Neves et al. 2015) and that population growth and urban expansion are important threats to biodiversity because of increasing exploitation rates (McGill et al. 2015). We used the most recent information regarding coastal population as a percentage of total state population (IBGE 2011).
All predictor variables were extracted from the landing data set and IBGE reports.

The final model was selected using a forward stepwise procedure from the starting model. To compare the goodness of fit between each model, two different measures were computed: the Watanabe-Akaike information criterion (WAIC) and the deviance information criterion (DIC). WAIC is a fully Bayesian measure that is better suited than the Akaike information criterion because it uses the entire posterior distribution to make inferences about the parameters and, therefore, provides more precise estimates (Watanabe 2010). DIC is the most popular measure to compare and select the best Bayesian model by a sensitivity analysis performance (Spiegelhalter et al. 2002). Only the final model will be considered and discussed, although the others will be shown as well. The analyses were carried out with the R-INLA package (Rue et al. 2009) of R software (R Core Team 2017) to perform the BGLM.

\section{RESULTS}

\section{Index of coastal vulnerability}

The average ICV for the Brazilian coast was 0.77 , which, according to the proposed qualitative scale (high category ranges from 0.61 to 0.80 ), is considered high vulnerability. The ICV ranged from 0.33 to 1 , with the state of Ceará $(\mathrm{ICV}=1)$ being the most vulnerable and Alagoas $(\mathrm{ICV}=0.33)$ the least vulnerable. Both states are located in the Northeastern ecoregion. Most states in the Northeastern and Eastern ecoregions presented higher scores than the Brazilian average, as did the states of Santa Catarina, in the Southeastern ecoregion, and Amapá, in the Amazonia ecoregion (Table 3, Fig. 3).

Fig. 3. Brazil study region showing all coastal states $(\mathrm{N}=17)$ colored according to the final Index of Coastal Vulnerability (ICV) score. The ICV scores ranged from 0.33 (low vulnerability) to 1.00 (high vulnerability). The average value for the index was 0.77 (high vulnerability). State acronyms: AL, Alagoas; AP, Amapá; BA, Bahia; CE, Ceará; ES, Espírito Santo; MA, Maranhão; PA, Pará; PB, Paraíba; PE, Pernambuco; PI, Piauí; PR, Paraná; RJ, Rio de Janeiro; RN, Rio Grande do Norte; RS, Rio Grande do Sul; SC, Santa Catarina; SE, Sergipe; SP, São Paulo.

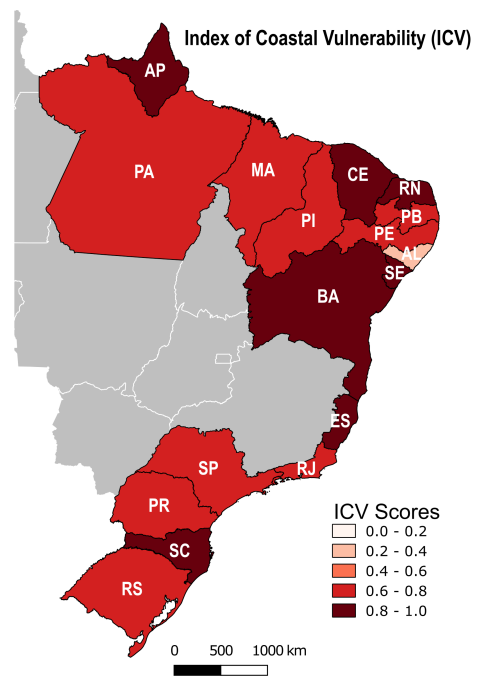


Table 3. Scores for the 3 components and the Index of Coastal Vulnerability (ICV) in the 5 Brazilian marine ecoregions and their 17 coastal states. Both the components and the index ranged from 0 to 1 . States with very high ICVs are in bold (ranges between 0.8 and $1.0)$.

\begin{tabular}{|c|c|c|c|c|c|}
\hline \multirow[b]{2}{*}{ Marine Ecoregion } & \multirow[b]{2}{*}{ States } & \multicolumn{3}{|c|}{ Components } & \multirow[b]{2}{*}{$\mathrm{ICV}$} \\
\hline & & $\begin{array}{l}\text { Adaptive } \\
\text { Capacity }\end{array}$ & $\begin{array}{c}\text { Species } \\
\text { Vulnerability }\end{array}$ & $\begin{array}{c}\text { Ecosystem } \\
\text { Vulnerability }\end{array}$ & \\
\hline \multirow[t]{3}{*}{ Amazonia } & Amapá (AP) & 0.51 & 0.59 & 0.80 & 0.98 \\
\hline & Pará (PA) & 0.83 & 0.60 & 0.80 & 0.63 \\
\hline & Maranhão (MA) & 0.82 & 0.54 & 0.90 & 0.68 \\
\hline \multirow[t]{7}{*}{ Northeastern } & Piauí (PI) & 0.83 & 0.58 & 0.96 & 0.79 \\
\hline & Ceará $(\mathrm{CE})$ & 0.71 & 0.63 & 0.98 & 1.00 \\
\hline & Rio Grande do Norte (RN) & 0.64 & 0.51 & 0.98 & 0.94 \\
\hline & Paraíba (PB) & 0.53 & 0.59 & 0.60 & 0.73 \\
\hline & Pernambuco (PE) & 0.50 & 0.57 & 0.60 & 0.74 \\
\hline & Alagoas (AL) & 0.82 & 0.51 & 0.60 & 0.33 \\
\hline & Sergipe (SE) & 0.64 & 0.48 & 0.98 & 0.91 \\
\hline \multirow[t]{3}{*}{ Eastern } & Bahia $(\mathrm{BA})^{\dagger}$ & 0.70 & 0.50 & 0.99 & 0.88 \\
\hline & Espírito Santo (ES) & 0.74 & 0.50 & 0.96 & 0.81 \\
\hline & Rio de Janeiro $(\mathrm{RJ})^{\dagger}$ & 0.88 & 0.60 & 0.97 & 0.77 \\
\hline \multirow[t]{3}{*}{ Southeastern } & São Paulo (SP) & 0.83 & 0.62 & 0.84 & 0.70 \\
\hline & Paraná (PR) & 0.74 & 0.40 & 0.90 & 0.61 \\
\hline & Santa Catarina $(\mathrm{SC})^{\dagger}$ & 0.64 & 0.53 & 0.90 & 0.87 \\
\hline \multirow[t]{2}{*}{ Rio Grande } & Rio Grande do Sul (RS) & 0.88 & 0.62 & 0.85 & 0.65 \\
\hline & Median & 0.74 & 0.57 & 0.90 & 0.77 \\
\hline
\end{tabular}

${ }^{\dagger}$ Coastal states that cover 2 marine ecoregions: Bahia = Northeastern and Eastern; Rio de Janeiro = Eastern and Southeastern; Santa Catarina = Southeastern and Rio Grande.

The average value for adaptive capacity was 0.74 and ranged from 0.50 to 0.88 . More than half of the states $(53 \%)$ presented scores below the national average. The state of Pernambuco had the lowest score $(\mathrm{AC}=0.50)$, and the states of Rio de Janeiro $(\mathrm{AC}=$ $0.88)$ and Rio Grande do Sul $(\mathrm{AC}=0.88)$ had the highest adaptive capacities. For the species vulnerability component, the country average was 0.57 and ranged from 0.40 to 0.63 among states. The vulnerability of fish species was highest in the state of Ceará (SP $=0.63)$ and lowest in Paraná $(\mathrm{SP}=0.40)$. Finally, the ecosystem component revealed that the state of Bahia $(\mathrm{ECO}=0.99)$ was more vulnerable than the others. The country average for this component was 0.90 and ranged from 0.60 to 0.99 (Table 3, Fig. 4).

In general, the species vulnerability component was classified as moderate, the adaptive capacity component as high vulnerability, and the ecosystem vulnerability was considered very high in almost all coastal states $(\mathrm{N}=14$; Table 3$)$. The coastal vulnerability index and the 3 vulnerability components revealed little variation among the 5 ecoregions. However, in general, the Amazonia and Northeastern ecoregions were more vulnerable. Almost half of the states presented ICV values classified as very high and above the national average values ( 0.77 out of 1$)$.

\section{Aspects defining coastal vulnerability in Brazil}

The final BGLM, based on the lowest WAIC, included fish landing richness and coastal population as relevant variables to explain coastal state ICVs (Table 4). There was a 79\% probability that states with lower numbers of species in their landings were more vulnerable (Fig. 5A), and a probability of $94 \%$ that a higher coastal population indicates higher coastal vulnerability (Fig. 5B). Stability in fish provision, the market indicator, and the extension of coastal states did not affect a state's vulnerability.
Table 4. Comparison of the Bayesian models used. Statistical acronyms: DIC, deviance information criterion; WAIC, Watanabe Akaike information criterion. Predictor acronyms: Coa_Ext, state coastal extension; Coa_Pop, percentage of coastal population; Insta, fisheries instability indicator; Mar, market index; Rich, landing richness. The model in bold was considered the best model.

\begin{tabular}{lll}
\hline \hline Model & WAIC & DIC \\
\hline 1 + Rich + Coa_Ext + Insta + Mar + Coa_Pop & -3.453 & -3.506 \\
1 + Rich + Insta + Market + Coa_Pop & -4.467 & -4.855 \\
1 + Rich + Coa_Ext + Market + Coa_Pop & -4.467 & -4.855 \\
1 + Rich + Market + Coa_Pop & -6.404 & -7.210 \\
1 + Rich + Insta + Coa_Pop & -6.446 & -7.036 \\
1 + Rich + Insta & -6.376 & -6.730 \\
1 + Rich + Coa_Pop & $\mathbf{- 8 . 3 3 1}$ & $\mathbf{- 9 . 2 8 8}$ \\
\hline
\end{tabular}

\section{DISCUSSION}

Notwithstanding the importance of the ecosystem services provided by coastal regions, increasing evidence indicates that coastal ecosystems have been deeply altered, thus reducing their productivity and resilience (Jackson et al. 2001, Ojea et al. 2017). Such effects have intensified conflicts over resources (Prestrelo and Vianna 2016), thereby affecting social-ecological vulnerability in coastal areas. The vulnerability index we created sought to develop an integrative approach that embraces different perspectives of the fisheries system. Given the difficulty and complexity in operationalizing vulnerability (Bennett et al. 2016, Comte et al. 2019), the ICV holistic approach helps untangle the root of anthropic stressors in coastal areas, given that centralized 
Fig. 4. Maps with all coastal states colored by final Index of Coastal Vulnerability (ICV) component scores: adaptive capacity (green scale), species vulnerability (orange scale), and ecosystem vulnerability (blue scale). All component scores were divided into 5 categories, with the lowest values represented by the lightest shades of the color scale. For the AC score only, the lower the value, the worse the situation. State acronyms: AL, Alagoas; AP, Amapá; BA, Bahia; CE, Ceará; ES, Espírito Santo; MA, Maranhão; PA, Pará; PB, Paraíba; PE, Pernambuco; PI, Piauí; PR, Paraná; RJ, Rio de Janeiro; RN, Rio Grande do Norte; RS, Rio Grande do Sul; SE, Sergipe; SC, Santa Catarina; SP, São Paulo.
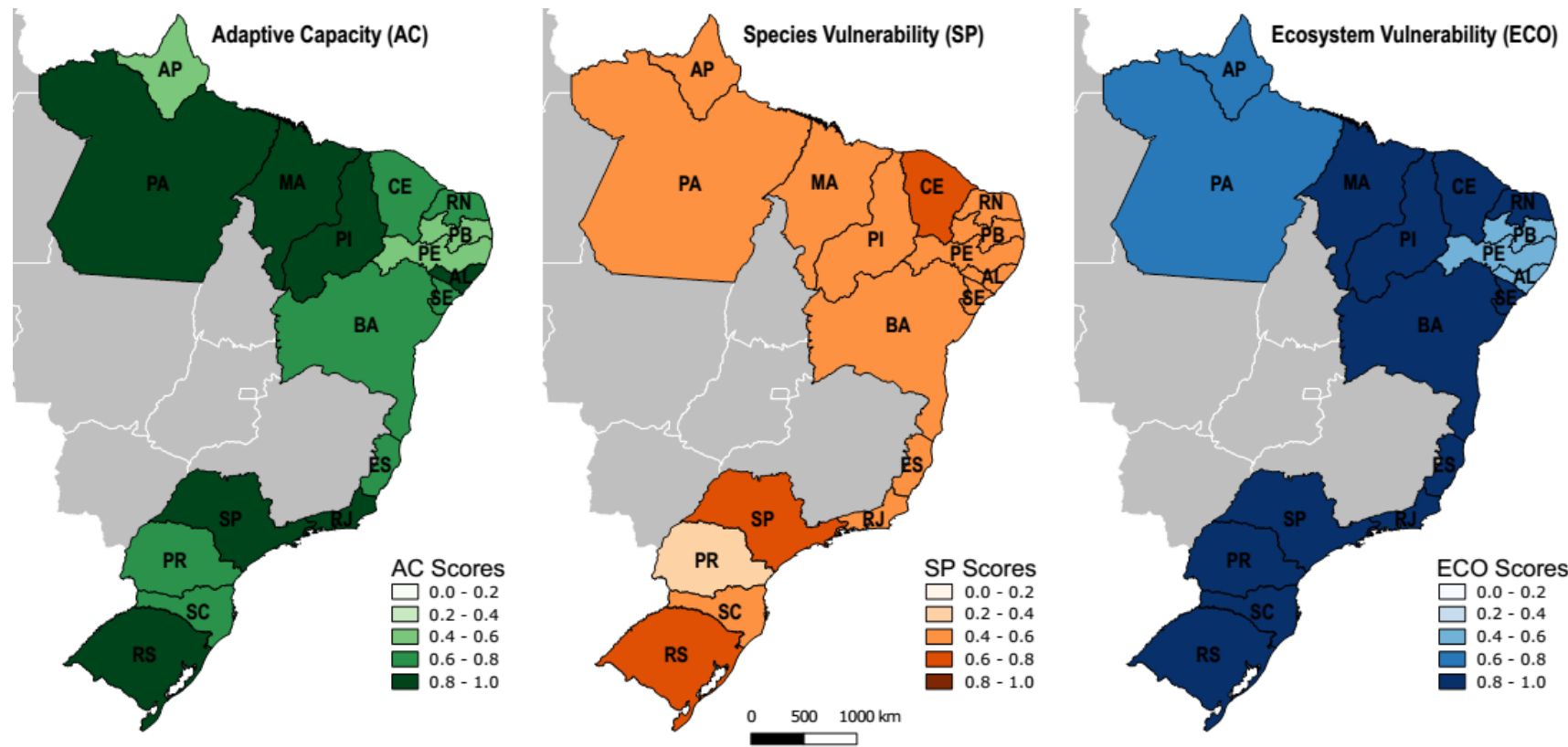

Fig. 5. Posterior probabilities of the relevant effects of the Bayesian model to landing richness (A) and coastal population (B) on coastal vulnerability.
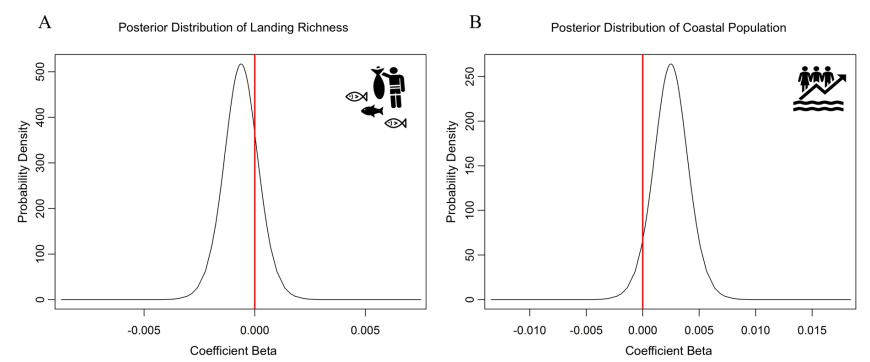

solutions to climate change seem insufficient. At the local level, the ICV facilitates assessments and comparative analyses of community vulnerability. Additionally, it enables a robust assessment of fisheries vulnerability and identifies locations where supplementary analyses should be conducted to better plan priorities for investment along the coast. By relating the ICV to external variables, it is also possible to identify the main drivers of poor vulnerability performance in a given region. For example, in the Brazilian case study we explored, the number of species presented in fish landings and the size of coastal populations were strongly related to coastal vulnerability. Our case study also highlighted how adaptive capacity alone, without investments in performance of how we exploit ecosystems services, is not enough to assure lower levels of SES vulnerability.
Considering the assessed components of the ICV, ecosystem vulnerability performed the worst, whereas climate exposure, primary productivity, and coastal protection presented high scores (above 0.9 points, the very high vulnerability category) and must be considered by managers (Appendix 5). Based on the climate scenarios that point toward a warmer future in Brazil, coastal ecosystems are expected to suffer thermal stress above their adaptative capacity (Soares et al. 2014, Bernardino et al. 2015). Thus, to prevent and minimize climate-induced damages to fishing SESs, ecosystem responses to global climate changes need to be taken seriously by improving the adaptive capacity and resilience of coastal communities to deal with future scenarios. Moreover, unsurprisingly, primary productivity and coastal protection performed badly. Fishery nursery areas, e.g., coral reefs and mangroves, in Brazil have been affected by many human threats, such as coastal development, pollution, deforestation, and, again, climate change (Prates et al. 2012). Some predictions have suggested that $40 \%$ of Brazilian reefs are at a high risk of declining in the very short term (Rodríguez-Ramírez et al. 2008). Estuarine environments, which support relevant ecological functions, are considered to be the most threatened coastal ecosystems in the Brazilian marine ecoregions (Bernardino et al. 2015, Sunday et al. 2015).

Although the Northeastern and Eastern ecoregions present moderate coastal habitat modification when compared with the other regions that have been severely modified (Heileman 2009), we have identified these to be the most vulnerable coastal areas. This is in accordance with a global study that analyzed species richness, endemism, and higher taxonomic uniqueness and 
concluded that the Northeastern ecoregion is vulnerable and should be included as a priority ecoregion for conservation purposes (Olson and Dinerstein 2002). For instance, the state of Rio Grande do Norte, which was identified to be the third most vulnerable state, showed the largest coastal degradation with about $56 \%$ of the mangrove area converted into shrimp farms (Prates et al. 2012). This state has also been affected by the high mobility of the industrial fleet from Ceará (Freire and Pauly 2010), the northeastern state in the worst situation.

Despite the increased effectiveness of Brazilian MPAs (Araújo and Bernard 2016), lack of protection, institutional support, and unsatisfactory management continue to be reported in coastal areas (Maretti 2001, Schiavetti et al. 2013, Santos and Schiavetti 2014). Additionally, MPAs still fail to protect critical nursery areas (Ervin et al. 2010, Nagelkerken et al. 2015), a factor widely aggravated by the biased distribution of MPAs across Brazilian ecoregions (Magris et al. 2013). Only part of the Northeastern marine ecoregion has some sort of no-take protection, and the distant islands of São Pedro and São Paulo lack protection entirely (Magris et al. 2013). Notwithstanding the proposed governmental initiatives to establish and monitor MPAs, which includes analyzing new priority areas along the coast (Prates et al. 2012), no concrete action has been taken.

On the other hand, adaptive capacity performed better than the other ICV components, which was mainly attributed to the fact that more than $50 \%$ of coastal municipalities have social and fisheries organizations. Communities that are more socially organized are considered less vulnerable because organization decreases the transaction costs for collective actions (Cinner et al. 2009). However, of the total 820,000 civil society organizations distributed throughout Brazil, there are only 2081 registered with the government that are associated with developing and advocating for the rights and interests of fishermen and fisherwomen (Lopez 2018). Despite the overall presence of social organizations, the low participation of people in local decision making has been widely recognized in coastal areas, including in Brazil (Lopes et al. 2011, Silva and Lopes 2015). Nevertheless, the existence of environmental laws, environmental councils, and some financial investment in environmental programs may nudge the political willingness toward supporting the protection of coastal areas. However, it is important to highlight that we considered only some aspects of human and social capital (e.g., educational attainment and presence of social organizations). Other adaptive capacity indicators, such as collective action, ability to organize, livelihood resources, and human conditions, should be considered in future studies whenever this information is available to refine the index.

Different fishers' groups from coastal communities can respond differently when facing ecosystem changes (Cinner et al. 2015, Silva and Lopes 2015). A clear role for people and the equitable sharing of costs and benefits is needed in vulnerability assessments (Tschakert et al. 2013). For instance, gender inequality has gained increasing attention in environmental management initiatives over the last decades (Agarwal 2010, Kleiber et al. 2017). Within small-scale fisheries, the recent female empowerment movement has promoted good examples of collective action and adaptation (Alonso-Población and Siar 2018, de la Torre-Castro 2019). Furthermore, given that over the last 10 years the Brazilian fishing policy (National Policy of Sustainable Development of the Aquaculture and Fisheries, Federal Law No. 11.959/2009; Federative Republic of Brazil 2009) has considered the production and repair of fishing gear and boats and fish processing to be fisheries activities, the percentage of fisherwomen has increased (Dias-Neto and Dias 2015). Still, the lack of social data on gender inequalities remains. Considering the social and gender inequalities in fisheries, any work toward decreasing them should have direct consequences on female livelihoods and female engagement in fisheries management and, thereby, reduce vulnerability and negative effects on the SESs (Biswas 2017). Although we do not have social data to analyze uneven vulnerabilities, we recognize this to be a fundamental contributing factor to achieving sustainable and equitable goals in marine conservation.

Similar to the other components of the ICV, the results of species vulnerability revealed regional differences. Although most species were found to have low threat levels (moderate vulnerability), the Northeastern and Eastern ecoregions included the most vulnerable states, mostly because of their elevated artisanal and industrial fishing pressures. Some species, e.g., Cynoscion acoupa, Lutjanus purpureus, Micropogonias furnieri, Mugil liza, Sardinella brasiliensis, Thunnus albacares, and Scomberomorus cavalla, are targeted by both sectors, whereas others have limited distribution ranges, e.g., Anchoviella spp., Cynoscion spp., Diapterus rhombeus, Haemulon plumierii, Lutjanus spp., Macrodon spp., M. furnieri, Opisthonema oglinum, S. brasiliensis, and Sparisoma spp. (Appendix 6). Distribution range, specifically, is one of the most important predictors of extinction risk among terrestrial and aquatic mammals (Davidson et al. 2009, 2012), amphibians, reptiles (Veron et al. 2016), and fish (Sunday et al. 2015). In the ocean, range shifts have been faster than in terrestrial ecosystems (Pinsky et al. 2013), and species with lower latitudinal ranges are more vulnerable because they become less able to find spots that fit their thermal preferences (Sunday et al. 2015). Some fish are also shifting to deeper waters or higher latitudes in response to climate change, e.g., because of increased seawater temperature, prey distribution, and so on (Perry et al. 2005). These changes in distribution patterns are likely to have tremendous impacts on fisheries and, consequently, result in alterations in community interactions. Thus, because local impacts could cause biodiversity loss of marine ecosystems on a global scale (Hawkins et al. 2000), it is crucial to consider the high vulnerability of restricted-range species in future coastal management to avoid even higher risks of extinction.

Although the ecosystem services approach has been largely incorporated into current societal discourse, anthropogenic influence on biodiversity loss will eventually threaten these services, especially through species extinctions caused by excessive fishing, pollution, habitat destruction, and other anthropogenic drivers (Cardinale et al. 2012, Bennett et al. 2016). Our findings agree with the Anthropocene concept applied to the fields of ecology and conservation, which refers to the epoch in which human impacts started to overtake natural processes (Gibbard and Walker 2014). Specifically, we observed that the lower the fish landing richness and the higher the coastal population, the higher the vulnerability of the state. This was an expected relationship because the typical models of human development in Brazil and in most places are based on the intensification of human 
exploitation of nearby coastal resources and increased coastal pollution, which affect coastal environments (Teixeira-Neves and Neves 2015, Hughes et al. 2017). Changing such models is a task that is overdue to be accepted, internalized, and performed by managers and policy makers, as we run out of time to maintain society's minimum livelihood standards.

\section{MANAGEMENT IMPLICATIONS FOR COASTAL VULNERABILITY IN BRAZIL}

The national score of 0.77 (out of 1) suggests that overall vulnerability is high, despite the high levels of adaptive capacity identified. Because of the low variation among ecoregions and/ or states, our findings suggest that the entire Brazilian coast has been widely compromised, making marine biodiversity conservation an urgent need. Some states, such as Ceará, clearly perform worse than others and require immediate attention.

In general, fishing communities in Brazil are culturally diverse, but characterized by the same precarious socioeconomic conditions and governability problems. This scenario can be smoothed by investments in coastal management to maintain long-term marine fisheries sustainability. Furthermore, to decrease the vulnerability of coastal habitats, we recommend enhancing fisheries management by monitoring coastal areas, restoring vulnerable habitats (mangroves, estuaries, and coral reefs), increasing actions to improve adaptive capacity, and expanding MPAs and comanagement approaches.

The low variation among marine ecoregions does not mean that the index is not effective at capturing changes over time, but rather that Brazilian coastal states share many similarities and have been affected by the same social and ecological problems. We suggest that this index be applied to other coastal systems for further evaluations and comparisons.

\section{BLIND SPOTS}

The ICV index helps determine the vulnerability of coastal communities in a straightforward way by synthesizing a complex system into a unique number that enables comparison of different areas. However, some gaps should be filled by further research to refine the index. For instance, fleet dynamics, such as size, and fleet mobility were not considered but could bring important information about fisheries dynamics and their impacts on the coast. Despite the fact that catch data is the most basic data needed to manage fish stocks, some countries, such as Brazil, do not have a history of fisheries statistics, thereby making it difficult to accurately define stocks in need of protection and measure coastal vulnerability accordingly. Additionally, even though our study supports the usefulness of the index for analysis on a local scale, some calibration would help its application in other coastal areas. In specific community-level scenarios, different variables may be required to form each indicator and component to track the context information of a given coastal area. Future research is also needed to identify better surrogates for social inequalities, to develop more appropriate objectives to represent minority social groups (e.g., fisherwomen), and to identify the processes that threaten them.

Even though the adaptive capacity component only has a few indicators, because of the data-poor situation in Brazil, when compared with the other components, the sensitivity analysis supported the robustness of the index. Still, whenever possible, additional measures of adaptive capacity should be used, such as those relating to diversity and occupation flexibility, e.g., livelihood characteristics and willingness to change; access to assets, e.g., cultural memory and natural capital; learning and knowledge, e.g., ability to learn and environmental perception; and governance and institutions, e.g., gender relations and levels of trust and cooperation (Adger 2006, Whitney et al. 2017).

However, the index was tested in a marine hot spot country, where coastal areas are undergoing negative changes faster than in other marine areas worldwide (Pecl et al. 2014). These marine hot spots are natural laboratories for social-ecological changes. They are also priority areas for research as they provide valuable case studies to help identify adaptation strategies that can be adopted in other coastal communities facing threats caused by a rapidly changing world (Pecl et al. 2014). Unfortunately, the index, whether applied to Brazil or elsewhere, is limited by the availability of reliable variables at different scales, making it difficult to have a more complete and expert-based process in the selection of variables. Despite these limitations, the ICV used robust Bayesian methods to analyze qualitative and quantitative data from socialecological fishery systems, an important new contribution to coastal fishery management in developing countries.

\section{CONCLUSIONS}

We are likely living in a catastrophic geologic era that demands new ways of thinking about human-nature relations. Our study helps us consider vulnerability in a new light, i.e., with a focus on communities and their individuals and experiences. At this level, it is possible to identify multiple interacting drivers of change and exposure to vulnerabilities and propose locally feasible solutions to improve the sustainability of human-coastal relationships. Among the most important advantages of the new index are its low cost to generate powerful results and its flexibility to adjust to other social-ecological contexts depending on data availability. However, it is important to highlight that, when applying the ICV to other contexts, it is necessary to adapt it to the local socialecological reality by considering the available variables without compromising the robustness of the index, for example, by attributing enough and meaningful variables to each component.

Our findings are consistent with the literature on small-scale fisheries in the Anthropocene that shows the risks derived from the rapid increase in population density in coastal areas. By pointing out weaker spots in the coastal system, the index helps provide some of the baseline necessary to manage fisheries in a holistic way with the goal of maintaining social-ecological benefits. Finally, there is growing scientific evidence about coastal vulnerabilities worldwide, and excuses about lack of knowledge will not be accepted in the future. It is past time we shed some light on the complex relationships in SES systems in the global south.

Responses to this article can be read online at: http://www.ecologyandsociety.org/issues/responses. php/11185 


\section{Acknowledgments:}

We acknowledge Lucyanno Fernandes for his great assistance in the spatial analysis using GIS. This study was financed in part by the Coordenação de Aperfeiçoamento de Pessoal de Nivel Superior Brasil (CAPES) - Finance Code 001. M. R. O. Silva thanks FAPERN for a doctorate grant. P. F. M. Lopes thanks CNPq for a productivity grant.

\section{LITERATURE CITED}

Adger, W. N. 2003. Social capital, collective action, and adaptation to climate change. Economic Geography 79 (4):387-404.

Adger, W. N. 2006. Vulnerability. Global Environmental Change 16(3):268-281. https://doi.org/10.1016/j.gloenvcha.2006.02.006

Agarwal, B. 2010. Gender and green governance: the political economy of women's presence within and beyond community forestry. Oxford University Press, Oxford, UK.

Allison, E. H., and B. Horemans. 2006. Putting the principles of the sustainable livelihoods approach into fisheries development policy and practice. Marine Policy 30(6):757-766. https://doi. org/10.1016/j.marpol.2006.02.001

Allison, E. H., A. L. Perry, M.-C. Badjeck, W. N. Adger, K. Brown, D. Conway, A. S. Halls, G. M. Piling, J. D. Reynolds, N. L. Andrew, and N. K. Dulvy. 2009. Vulnerability of national economies to the impacts of climate change on fisheries. Fish and Fisheries 10(2):173-196. https://doi.org/10.1111/j.1467-2979.2008.00310. $\underline{x}$

Alonso-Población, E., and S. V. Siar. 2018. Women's participation and peadership in fisherfolk organizations and collective action in fisheries: a review of evidence on enablers, drivers and barriers. FAO Fisheries and Aquaculture Circular No. 1159. Food and Agriculture Organization of the United Nations, Rome, Italy.

Araújo, J. L., and E. Bernard. 2016. Management effectiveness of a large marine protected area in northeastern Brazil. Ocean \& Coastal Management 130:43-49. https://doi.org/10.1016/j. ocecoaman.2016.05.009

Assis, J., L. Tyberghein, S. Bosh, H. Verbruggen, E. A. Serrão, and O. De Clerck. 2018. Bio-ORACLE v2.0: extending marine data layers for bioclimatic modelling. Global Ecology and Biogeography 27(3):277-284. https://doi.org/10.1111/geb.12693

Aswani, S., X. Basurto, S. Ferse, M. Glaser, L. Campbell, J. E. Cinner, T. Dalton, L. D. Jenkins, M. L. Miller, R. Pollnac, I. Vaccaro, and P. Christie. 2018. Marine resource management and conservation in the Anthropocene. Environmental Conservation 45(2):192-202. https://doi.org/10.1017/S0376892917000431

Aswani, S., J. A. E. Howard, M. A. Gasalla, S. Jennings, W. Malherbe, I. M. Martins, S. S. Salim, I. E. Van Putten, P. S. Swathilekshmi, R. Narayanakumar, and G. R. Watmough. 2019. An integrated framework for assessing coastal community vulnerability across cultures, oceans and scales. Climate and Development 11(4):365-382. https://doi.org/10.1080/17565529.2$\underline{018.1442795}$
Basurto, X., J. Virdin, H. Smith, and R. Juskus. 2017. Strengthening governance of small-scale fisheries: an initial assessment of theory and practice. Oak Foundation, Geneva, Switzerland.

Beck, M. W., editor. 2014. Coasts at risk: an assessment of coastal risks and the role of environmental solutions. United Nations University-Institute for Environment and Human Security, Bonn, Germany; The Nature Conservancy, Arlington, Virginia, USA; and Coastal Resources Center, The University of Rhode Island, Graduate School of Oceanography, Narragansett, Rhode Island, USA.

Béné, C., R. M. Al-Hassan, O. Amarasinghe, P. Fong, J. Ocran, E. Onumah, R. Ratuniata, T. Van Tuyen, J. A. McGregor, and D. J. Mills. 2016. Is resilience socially constructed? Empirical evidence from Fiji, Ghana, Sri Lanka, and Vietnam. Global Environmental Change 38:153-170. https://doi.org/10.1016/j. gloenvcha.2016.03.005

Béné, C., F. S. Chowdhury, M. Rashid, S. A. Dhali, and F. Jahan. 2017. Squaring the circle: reconciling the need for rigor with the reality on the ground in resilience impact assessment. World Development 97:212-231. https://doi.org/10.1016/j.worlddev.2017.04.011

Bennett, N. J., J. Blythe, S. Tyler, and N. C. Ban. 2016. Communities and change in the Anthropocene: understanding social-ecological vulnerability and planning adaptations to multiple interacting exposures. Regional Environmental Change 16:907-926. https://doi.org/10.1007/s10113-015-0839-5

Bennett, N. J., P. Dearden, and A. M. Peredo. 2015. Vulnerability to multiple stressors in coastal communities: a study case of the Andaman coast of Thailand. Climate and Development 7 (2):124-141. https://doi.org/10.1080/17565529.2014.886993

Bennett, N. J., A. Di Franco, A. Calò, E. Nethery, F. Niccolini, M. Milazzo, and P. Guidetti. 2019. Local support for conservation is associated with perceptions of good governance, social impacts, and ecological effectiveness. Conservation Letters 12(4):e12640. https://doi.org/10.1111/conl.12640

Bennett, N. J., R. Roth, S. C. Klain, K. M. A. Chan, D. A. Clark, G. Cullman, G. Epstein, M. P. Nelson, R. Stedman, T. L. Teel, R. E. W. Thomas, C. Wyborn, D. Curran, A. Greenberg, J. Sandlos, and D. Veríssimo. 2017. Mainstreaming the social sciences in conservation. Conservation Biology 31(1):56-66. https://doi. org/10.1111/cobi.12788

Bennett, N. J., and T. Satterfield. 2018. Environmental governance: a practical framework to guide design, evaluation and analysis. Conservation Letters 11(6):e12600. https://doi. org/10.1111/conl.12600

Berkes, F., and C. Folke. 1998. Linking social and ecological systems for resilience and sustainability. Pages 1-25 in F. Berkes, C. Folke, and J. Colding, editors. Linking social and ecological systems: management practices and social mechanisms for building resilience. Cambridge University Press, Cambridge, UK.

Berkes, F., C. Folke, and J. Colding. 2000. Linking social and ecological systems: management practices and social mechanisms for building resilience. Cambridge University Press, Cambridge, UK. 
Bernardino, A. F., S. A. Netto, P. R. Pagliosa, F. Barros, R. A. Christofoletti, J. S. Rosa Filho, A. Colling, and P. C. Lana. 2015. Predicting ecological changes on benthic estuarine assemblages through decadal climate trends along Brazilian marine ecoregions. Estuarine, Coastal and Shelf Science 166A:74-82. https://doi.org/10.1016/j.ecss.2015.05.021

Biswas, N. 2017. Towards gender-equitable small-scale fisheries governance and development: a handbook in support of the implementation of the voluntary guidelines for securing sustainable small-scale fisheries in the context of food security and poverty eradication. Food and Agriculture Organization of the United Nations, Rome, Italy.

Brazilian Institute of Geography and Statistics (IBGE). 2011. Censo demográfico 2010: Características da população e dos domicílios - Resultados do universo. IBGE, Rio de Janeiro, Brazil.

Buckle, P., G. Marsh, and S. Smale. 2001. Assessing resilience and vulnerability: principles, strategies and actions. Emergency Management Australia, Canberra, Australian Capital Territory, Australia.

Cardinale, B. J., J. E. Duffy, A. Gonzalez, D. U. Hooper, C. Perrings, P. Venail, A. Narwani, G. M. Mace, D. Tilman, D. A. Wardle, A. P. Kinzig, G. C. Daily, M. Loreau, J. B. Grace, A. Larigauderie, D. S. Srivastava, and S. Naeem. 2012. Biodiversity loss and its impact on humanity. Nature 486(7401):59-67. https:// $\underline{\text { doi.org/10.1038/nature11148 }}$

Christensen, V., M. Coll, C. Piroddi, J. Steenbeek, J. Buszowski, and D. Pauly. 2014. A century of fish biomass decline in the ocean. Marine Ecology Progress Series 512:155-166. https://doi. org/10.3354/meps 10946

Cinner, J., M. M. P. B. Fuentes, and H. Randriamahazo. 2009. Exploring social resilience in Madagascar's marine protected areas. Ecology and Society 14(1):41. https://doi.org/10.5751/ ES-02881-140141

Cinner, J. E., C. Huchery, E. S. Darling, A. T. Humphries, N. A. J. Graham, C. C. Hicks, N. Marshall, and T. R. McClanahan. 2013. Evaluating social and ecological vulnerability of coral reef fisheries to climate change. PLOS ONE 8(9):e74321. https://doi. org/10.1371/journal.pone.0074321

Cinner, J. E., C. Huchery, C. C. Hicks, T. M. Daw, N. Marshall, A. Wamukota, and E. H. Allison. 2015. Changes in adaptive capacity of Kenyan fishing communities. Nature Climate Change 5(9):872-876. https://doi.org/10.1038/nclimate2690

Comte, A., L. H. Pendleton, D. Bailly, and E. Quillérou. 2019. Conceptual advances on global scale assessments of vulnerability: informing investments for coastal populations at risk of climate change. Marine Policy 99:391-399. https://doi.org/10.1016/j. marpol.2018.10.038

Corlett, R. T. 2015. The Anthropocene concept in ecology and conservation. Trends in Ecology \& Evolution 30(1):36-41. https:// doi.org/10.1016/j.tree.2014.10.007

Davidson, A. D., A. G. Boyer, H. Kim, S. Pompa-Mansilla, M. J. Hamilton, D. P. Costa, G. Ceballos, and J. H. Brown. 2012. Drivers and hotspots of extinction risk in marine mammals. Proceedings of the National Academy of Sciences of the United
States of America 109(9):3395-3400. https://doi.org/10.1073/ pnas. 1121469109

Davidson, A. D., M. J. Hamilton, A. G. Boyer, J. H. Brown, and G. Ceballos. 2009. Multiple ecological pathways to extinction in mammals. Proceedings of the National Academy of Sciences of the United States of America 106(26):10702-10705. https://doi. org/10.1073/pnas.0901956106

Daw, T. M., C. Hicks, K. Brown, T. Chaigneau, F. JanuchowskiHartley, W. Cheung, S. Rosendo, B. Crona, S. Coulthard, C. Sandbrook, C. Perry, S. Bandeira, N. A. Muthiga, B. SchulteHerbrüggen, J. Bosire, and T. R. McClanahan. 2016. Elasticity in ecosystem services: exploring the variable relationship between ecosystems and human well-being. Ecology and Society 21(2):11. http://dx.doi.org/10.5751/ES-08173-210211

de la Torre-Castro, M. 2019. Inclusive management through gender consideration in small-scale fisheries: the why and the how. Frontiers in Marine Science 6:156. https://doi.org/10.3389/ fmars.2019.00156

Dias-Neto, J. 2010. Pesca no Brasil e seus aspectos institucionaisum registro para o futuro. Revista CEPSUL-Biodiversidade $e$ Conservação Marinha 1 (1):66-80.

Dias-Neto, J., and J. F. O. Dias. 2015. O uso da biodiversidade aquática no Brasil: uma avaliação com foco na pesca. Ibama, Brasília, Brazil.

Di Ciommo, R. C., and A. Schiavetti. 2012. Women participation in the management of a marine protected area in Brazil. Ocean \& Coastal Management 62:15-23. https://doi.org/10.1016/j. ocecoaman.2012.02.010

Dolan, A. H., and I. J. Walker. 2004. Understanding vulnerability of coastal communities to climate change related risks. Journal of Coastal Research SI39:1316-1323.

Elfes, C. T., C. Longo, B. S. Halpern, D. Hardy, C. Scarborough, B. D. Best, T. Pinheiro, and G. F. Dutra. 2014. A regional-scale Ocean Health Index for Brazil. PLoS ONE 9(4):e92589. https:// doi.org/10.1371/journal.pone.0092589

Ervin, J., K. J. Mulongoy, K. Lawrence, E. Game, D. Sheppard, P. Bridgewater, G. Bennet, S. B. Gidda, and P. Bos. 2010. Making protected areas relevant: a guide to integrating protected areas into wider landscapes, seascapes and sectoral plans and strategies. CBD Technical Series 44(5):1-94.

Federative Republic of Brazil. 2009. Lei No. 11.959 de 29 de junho de 2009. Dispõe sobre a Politica Nacional de Desenvolvimento Sustentável da Aquicultura e da Pesca, regula as atividades pesqueiras, revoga a Lei No. 7.679, de 23 de novembro de 1988, e dispositivos do Decreto-Lei No. 221, de 28 de fevereiro de 1967, e dá outras providências. Diário Oficial da República Federativa do Brasil, Brasília, Brazil.

Food and Agriculture Organization of the United Nations (FAO). 2012. The state of world fisheries and aquaculture 2012. FAO, Rome, Italy.

Food and Agriculture Organization of the United Nations (FAO). 2016. The state of world fisheries and aquaculture. FAO, Rome, Italy. 
Freire, K. M. F., J. A. N. Aragão, A. R. R. Araújo, A. O. Ávilada-Silva, M. C. S. Bispo, G. V. Canziani, M. H. Carneiro, F. D. S. Gonçalves, K. A. Keunecke, J. T. Mendonça, P. S. Moro, F. S. Motta, G. Olavo, P. R. Pezzuto, R. F. Santana, R. A. dos Santos, I. Trindade-Santos, J. A. Vasconcelos, M. Vianna, and E. Divovich. 2014. Revisiting Brazilian catch data for Brazilian marine waters (1950-2010). Working Paper \#2014-23. The Fisheries Centre, University of British Columbia, Vancouver, British Columbia, Canada.

Freire, K. M. F., J. A. N. Aragão, A. R. R. Araújo, A. O. Ávilada-Silva, M. C. S. Bispo, G. Velasco, M. H. Carneiro, F. D. S. Gonçalves, K. A. Keunecke, J. T. Mendonça, P. S. Moro, F. S. Motta, G. Olavo, P. R. Pezzuto, R. F. Santana, R. A. dos Santos, I. Trindade-Santos, J. A. Vasconcelos, M. Vianna, and E. Divovich. 2015. Reconstruction of catch statistics for Brazilian marine waters (1950-2010). Pages 3-30 in K. M. F. Freire and D. Pauly, editors. Fisheries catch reconstructions for Brazil's mainland and oceanic islands. Fisheries Centre Research Reports 23(4). The Fisheries Centre, University of British Columbia, Vancouver, British Columbia, Canada.

Freire, K. M. F., and D. Pauly. 2010. Fishing down Brazilian marine food webs, with emphasis on the East Brazil large marine ecosystem. Fisheries Research 105(1):57-62. https://doi. org/10.1016/j.fishres.2010.02.008

Froese, R., and D. Pauly, editors. 2017. FishBase. World Wide Web eletronic publication. [online] URL: http://fishbase.org

Gibbard, P. L., and M. J. C. Walker. 2014. The term 'Anthropocene' in the context of formal geological classification. Geological Society, London, Special Publications 395:29-37. https://doi.org/10.1144/SP395.1

Godfray, H. C. J., J. R. Beddington, I. R. Crute, L. Haddad, D. Lawrence, J. F. Muir, J. Pretty, S. Robinson, S. M. Thomas, and C. Toulmin. 2010. Food security: the challenge of feeding 9 billion people. Science 327(5967):812-818. https://doi.org/10.1126/ science. 1185383

Gunderson, L. 2010. Ecological and human community resilience in response to natural disasters. Ecology and Society 15(2):18. https://doi.org/10.5751/ES-03381-150218

Harper, S., D. Zeller, M. Hauzer, D. Pauly, and U. R. Sumaila. 2013. Women and fisheries: contribution to food security and local economies. Marine Policy 39:56-63. https://doi.org/10.1016/ j.marpol.2012.10.018

Hawkins, J. P., C. M. Roberts, and V. Clark. 2000. The threatened status of restricted-range coral reef fish species. Animal Conservation 3(1):81-88. https://doi.org/10.1111/j.1469-1795.2000. tb00089.x

Heileman, S. 2009. XVI-53 East Brazil Shelf: LME \#16. Pages 735-745 in K. Sherman and G. Hempel, editors. The UNEP large marine ecosystem report: a perspective on changing conditions in LMEs of the world's regional seas. UNEP Regional Seas Report and Studies No. 182. United Nations Environment Programme, Nairobi, Kenya.

Hinkel, J. 2011. "Indicators of vulnerability and adaptive capacity": towards a clarification of the science-policy interface. Global Environmental Change 21(1):198-208. https://doi. org/10.1016/j.gloenvcha.2010.08.002
Hughes, T. P., M. L. Barnes, D. R. Bellwood, J. E. Cinner, G. S. Cumming, J. B. C. Jackson, J. Kleypas, I. A. van de Leemput, J. M. Lough, T. H. Morrison, S. R. Palumbi, E. H. van Nes, and M. Scheffer. 2017. Coral reefs in the Anthropocene. Nature 546 (7656):82-90. https://doi.org/10.1038/nature22901

Hughes, S., A. Yau, L. Max, N. Petrovic, F. Davenport, M. Marshall, T. R. McClanahan, E. H. Allison, and J. E. Cinner. 2012. A framework to assess national level vulnerability from the perspective of food security: the case of coral reef fisheries. Environmental Science \& Policy 23:95-108. https://doi. org/10.1016/j.envsci.2012.07.012

Institute of Applied Economic Research (IPEA). 2017. Mapa das Organizações da Sociedade Civil. IPEA, Brasília, Brazil.

Intergovernmental Panel on Climate Change (IPCC). 2001. Climate change 2001: impacts, adaptation, and vulnerability. Contribution of Working Group II to the Third Assessment Report of the Intergovernmental Panel on Climate Change. Cambridge University Press, Cambridge, UK.

Intergovernmental Panel on Climate Change (IPCC). 2012. Managing the risks of extreme events and disasters to advance climate change adaptation. Special Report of the Intergovernmental Panel on Climate Change. Cambridge University Press, Cambridge, UK. https://doi.org/10.1017/CBO9781139177245

Intergovernmental Panel on Climate Change (IPCC). 2014. Climate change 2014: impacts, adaptation and vulnerability. Part A: global and sectoral aspects. Contribution of Working Group II to the Fifth Assessment Report of the Intergovernmental Panel on Climate Change. Cambridge University Press, Cambridge, UK.

Jackson, J. B. C., M. X. Kirby, W. H. Berger, K. A. Bjorndal, L. W. Botsford, B. J. Bourque, R. H. Bradbury, R. Cooke, J. Erlandson, J. A. Estes, T. P. Hughes, S. Kidwell, C. B. Lange, H. S. Lenihan, J. M. Pandolfi, C. H. Peterson, R. S. Steneck, M. J. Tegner, and R. R. Warner. 2001. Historical overfishing and the recent collapse of coastal ecosystems. Science 293:629-637. https://doi.org/10.1126/science.1059199

Kalikoski, D. C., C. S. Seixas, and T. Almudi. 2009. Gestão compartilhada e comunitária da pesca no Brasil: avanços e desafios. Ambiente \& Sociedade 12(1):151-172. https://doi. org/10.1590/S1414-753X2009000100011

Khan, A. S., and G. Cundill. 2019. Hotspots 2.0: toward an integrated understanding of stressors and response options. Ambio: A Journal of the Human Environment 48(6):639-648. https://doi.org/10.1007/s13280-018-1120-1

Khan, A., G. Cundill Kemp, B. Currie-Alder, and M. Leone. 2018. Responding to uneven vulnerabilities: a synthesis of emerging insights from climate change hotspots. CARIAA Working Paper No. 22. International Development Research Centre, Ottawa, Ontario, Canada.

Kleiber, D., K. Frangoudes, H. T. Snyder, A. Choudhury, S. M. Cole, K. Soejima, C. Pita, A. Santos, C. McDougall, H. Petrics, and M. Porter. 2017. Promoting gender equity and equality through the small-scale fisheries guidelines: experiences from multiple case studies. Pages 737-759 in S. Jentoft, R. Chuenpagdee, M. J. Barragán-Paladines, and N. Franz, editors. The small- scale fisheries guidelines: global implementation. 
MARE Publication Series Volume 14. Springer, Cham, Switzerland. https://doi.org/10.1007/978-3-319-55074-9 35

Kleisner, K. M., C. Longo, M. Coll, B. S. Halpern, D. Hardy, S. K. Katona, F. Le Manach, D. Pauly, A. A. Rosenberg, J. F. Samhouri, C. Scarborough, U. R. Sumaila, R. Watson, and D. Zeller. 2013b. Exploring patterns of seafood provision revealed in the global Ocean Health Index. Ambio: A Journal of the Human Environment 42(8):910-922. https://doi.org/10.1007/s13280-013-0447$\underline{\mathrm{x}}$

Kleisner, K., D. Zeller, R. Froese, and D. Pauly. 2013a. Using global catch data for inferences on the world's marine fisheries. Fish and Fisheries 14(3):293-311. https://doi.org/10.1111/ j.1467-2979.2012.00469.x

Lebel, L., J. M. Anderies, B. Campbell, C. Folke, S. HatfieldDodds, T. P. Hughes, and J. Wilson. 2006. Governance and the capacity to manage resilience in regional social-ecological systems. Ecology and Society 11(1):19. https://doi.org/10.5751/ ES-01606-110119

Lee, C. K. F., C. Duncan, H. J. F. Owen, and N. Pettorelli. 2018. A new framework to assess relative ecosystem vulnerability to climate change. Conservation Letters 11(2):e12372. https://doi. org/10.1111/conl.12372

Liu, J., T. Dietz, S. R. Carpenter, C. Folke, M. Alberti, C. L. Redman, S. H. Schneider, E. Ostrom, A. N. Pell, J. Lubchenco, W. W. Taylor, Z. Ouyang, P. Deadman, T. Kratz, and W. Provencher. 2007. Coupled human and natural systems. Ambio: A Journal of the Human Environment 36(8):639-649. https://doi. org/10.1579/0044-7447(2007)36[639:CHANS]2.0.CO:2

Lopes, P. F. M., R. A. M. Silvano, and A. Begossi. 2011. Extractive and sustainable development reserves in Brazil: resilient alternatives to fisheries? Journal of Environmental Planning and Management 54(4):421-443. https://doi.org/10.1080/09640568.2$\underline{010.508687}$

Lopez, F. G. 2018. Perfil das organizações da sociedade civil no Brasil. Institute of Applied Economic Research (IPEA), Brasília, Brazil.

López-Angarita, J., R. Moreno-Sánchez, J. H. Maldonado, and J. A. Sánchez. 2014. Evaluating linked social-ecological systems in marine protected areas. Conservation Letters 7(3):241-252. https://doi.org/10.1111/conl.12063

Lovelock, C. E., D. R. Cahoon, D. A. Friess, G. R. Guntenspergen, K. W. Krauss, R. Reef, K. Rogers, M. L. Saunders, F. Sidik, A. Swales, N. Saintilan, L. X. Thuyen, and T. Triet. 2015. The vulnerability of Indo-Pacific mangrove forests to sea-level rise. Nature 526(7574):559-563. https://doi.org/10.1038/ nature 15538

Magris, R. A., M. Mills, M. M. P. B. Fuentes, and R. L. Pressey. 2013. Analysis of progress towards a comprehensive system of marine protected areas in Brazil. Natureza e Conservação 11 (1):81-87. https://doi.org/10.4322/natcon.2013.013

Mamauag, S. S., P. M. Aliño, R. J. S. Martinez, R. N. Muallil, M. V. A. Doctor, E. C. Dizon, R. C. Geronimo, F. M. Panga, and R. B. Cabral. 2013. A framework for vulnerability assessment of coastal fisheries ecosystems to climate change-tool for understanding resilience of fisheries (VA-TURF). Fisheries Research 147:381-393. https://doi.org/10.1016/j.fishres.2013.07.007

Maretti, C. 2001. Comentários sobre a Situação das Unidades de Conservação no Brasil. Revista d direitos difusos 5:633-652.

Marshall, N. A., and P. A. Marshall. 2007. Conceptualizing and operationalizing social resilience within commercial fisheries in northern Australia. Ecology and Society 12(1):1. https://doi. org/10.5751/ES-01940-120101

Marshall, N. A., C. R. Tobin, P. A. Marshall, M. Gooch, and A. J. Hobday. 2013. Social vulnerability of marine resource users to extreme weather events. Ecosystems 16(5):797-809. http://dx.doi. org/10.1007/s10021-013-9651-6

McClanahan, T. R., J. E. Cinner, J. Maina, N. A. J. Graham, T. M. Daw, S. M. Stead, A. Wamukota, K. Brown, M. Ateweberhan, V. Venus, and N. V. C. Polunin. 2008. Conservation action in a changing climate. Conservation Letters 1(2):53-59. https://doi. org/10.1111/j.1755-263X.2008.00008 1.X

McGill, B. J., M. Dornelas, N. J. Gotelli, and A. E. Magurran. 2015. Fifteen forms of biodiversity trend in the Anthropocene. Trends in Ecology \& Evolution 30(2):104-113. https://doi. org/10.1016/j.tree.2014.11.006

Metcalf, S. J., E. I. Van Putten, S. Frusher, N. A. Marshall, M. Tull, N. Caputi, M. Haward, A. J. Hobday, N. J. Holbrook, S. M. Jennings, G. T. Pecl, and J. Shaw. 2015. Measuring the vulnerability of marine social-ecological systems: a prerequisite for the identification of climate change adaptations. Ecology and Society 20(2):35. http://dx.doi.org/10.5751/ES-07509-200235

Millenium Ecosystem Assessment. 2005. Ecosystems and human well-being. World Resources Institute and Island, Washington, D. C., USA.

Ministério da Pesca e Aquicultura. 2013. Boletim do Registro Geral da Atividade Pesqueira - RGP 2012. Ministério da Pesca e Aquicultura, Brasília, Brazil.

Ministério do Meio Ambiente (MMA). 2011. Quarto relatório nacional para a convenção sobre diversidade biológica: Brasil. Biodiversidade 38. MMA, Brasília, Brazil.

Moreno-Sánchez, R. P., and J. H. Maldonado. 2013. Adaptive capacity of fishing communities at marine protected areas: a case study from the Colombian Pacific. Ambio: A Journal of the Human Environment 42(8):985-996. https://doi.org/10.1007/ s13280-013-0454-y

Nagelkerken, I., M. Sheaves, R. Baker, and R. M. Connolly. 2015. The seascape nursery: a novel spatial approach to identify and manage nurseries for coastal marine fauna. Fish and Fisheries 16 (2):362-371. https://doi.org/10.1111/faf.12057

O'Brien, K., S. Eriksen, L. P. Nygaard, and A. Schjolden. 2007. Why different interpretations of vulnerability matter in climate change discourses. Climate Policy 7(1):73-88. https://doi. org/10.3763/cpol.2007.0706

O'Brien, K., A. L. St. Clair, and B. Kristoffersen. 2010. Climate change, ethics and human security. Cambridge University Press, Cambridge, UK. https://doi.org/10.1017/CBO9780511762475 
Ojea, E., I. Pearlman, S. D. Gaines, and S. E. Lester. 2017. Fisheries regulatory regimes and resilience to climate change. Ambio: A Journal of the Human Environment 46(4):399-412. https://doi.org/10.1007/s13280-016-0850-1

Olson, D. M., and E. Dinerstein. 2002. The Global 200: priority ecoregions for global conservation. Annals of the Missouri Botanical Garden 89(2):199-224. https://doi.org/10.2307/3298564

Orencio, P. M., and M. Fujii. 2013. An index to determine vulnerability of communities in a coastal zone: a case study of Baler, Aurora, Philippines. Ambio: A Journal of the Human Environment 42(1):61-71. https://doi.org/10.1007/s13280-012-0331-0

Pecl, G. T., A. J. Hobday, S. Frusher, W. H. H, Sauer, and A. E. Bates. 2014. Ocean warming hotspots provide early warning laboratories for climate change impacts. Reviews in Fish Biology and Fisheries 24(2):409-413. https://doi.org/10.1007/s11160-014-9355-9

Perry, A. L., P. J. Low, J. R. Ellis, and J. D. Reynolds. 2005. Climate change and distribution shifts in marine fishes. Science 308 (5730):1912-1915. https://doi.org/10.1126/science.1111322

Perry, R. I., R. E. Ommer, E. H. Allison, M.-C. Badjeck, M. Barange, L. Hamilton, A. Jarre, R. A. Quiñones, and R. U. Sumaila. 2010. Interactions between changes in marine ecosystems and human communities. Pages 221-252 in $\mathrm{M}$. Barange, J. G. Field, and P. Harris, E. E. Hofmann, R. I. Perry, and F. Werner, editors. Marine ecosystems and global change. Oxford University Press, Oxford, UK. https://doi.org/10.1093/ acprof:oso/9780199558025.003.0008

Pinsky, M. L., B. Worm, M. J. Fogarty, J. L. Sarmiento, and S. A. Levin. 2013. Marine taxa track local climate velocities. Science 341:1239-1242. https://doi.org/10.1126/science.1239352

Pomeroy, R., J. Parks, K. L. Mrakovcich, and C. LaMonica. 2016. Drivers and impacts of fisheries scarcity, competition, and conflict on maritime security. Marine Policy 67:94-104. https:// doi.org/10.1016/j.marpol.2016.01.005

Prates, A. P. L., M. A. Gonçalves, and M. R. Rosa. 2012. Panorama da Conservação dos Ecossistemas Costeiros e Marinhos no Brasil. Ministério do Meio Ambiente, Secretaria de Biodiversidade e Florestas, Gerência de Biodiversidade Aquática e Recursos Pesqueiros, Brasília, Brazil.

Prestrelo, L., and E. M. Vianna. 2016. Identifying multiple-use conflicts prior to marine spatial planning: a case study of a multilegislative estuary in Brazil. Marine Policy 67:83-93. https://doi. org/10.1016/j.marpol.2016.02.001

R Core Team. 2017. R: a language and environment for statistical computing. R Foundation for Statistical Computing, Vienna, Austria.

Reis, R. E., J. S. Albert, F. Di Dario, M. M. Mincarone, P. Petry, and L. A. Rocha. 2016. Fish biodiversity and conservation in South America. Journal of Fish Biology 89(1):12-47. https://doi. org/10.1111/jfb. 13016

Ripple, W. J., C. Wolf, T. M. Newsome, M. Galetti, M. Alamgir, E. Crist, M. I. Mahmoud, W. F. Laurance, and 15,364 scientist signatories from 184 countries. 2017. World scientists' warning to humanity: a second notice. BioScience 67(12):1026-1028. https:// doi.org/10.1093/biosci/bix125
Rodríguez-Ramírez, A., C. Bastidas, J. Cortés, H. Guzmán, Z. Leão, J. Garzón-Ferreira, R. Kikuchi, B. Padovani Ferreira, J. J. Alvarado, C. Jimenez, A. C. Fonseca, E. Salas, J. Nivia, C. Fernández, S. Rodriguez, D. Debrot, A. Cróquer, D. Gil, D. I. Gómez, R. Navas-Camacho, M. C. Reyes-Nivia, A. Acosta, E. Alvarado, V. Pizarro, A. Sanjuan, P. Herrón, F. A. Zapata, S. Zea, M. López-Victoria, and J. A. Sanchez. 2008. Status of coral reefs and associated ecosystems in southern tropical America: Brazil, Colombia, Costa Rica, Panamá and Venezuela. Pages 281-294 in C. Wilkinson, editor. Status of coral reefs of the world: 2008. Global Coral Reef Monitoring Network and Reef and Rainforest Research Centre, Townsville, Queensland, Australia.

Rue, H., S. Martino, and N. Chopin. 2009. Approximate Bayesian inference for latent Gaussian models by using integrated nested Laplace approximations. Journal of the Royal Statistical Society: Series B (Statistical Methodology) 71(2):319-392. https://doi. org/10.1111/j.1467-9868.2008.00700.x

Ruffino, M. L., and P. R. Abdallah. 2016. Fisheries subsidies in Brazil in the century XX - statistics and discussion. In $54^{\circ}$ Congresso da Sociedade Brasileira de Economia, Administração e Sociologia Rural, 2016, Maceió. Desenvolvimento, território e biodiversidade. Editora da UFAL, Maceió, Brazil.

Santos, C. Z., and A. Schiavetti. 2014. Spatial analysis of protected areas of the coastal/marine environment of Brazil. Journal of Nature Conservation 22(5):453-461. https://doi. org/10.1016/j.jnc.2014.05.001

Schiavetti, A., J. Manz, C. Zapelini dos Santos, T. C. Magro, and M. I. Pagani. 2013. Ocean \& coastal management marine protected areas in Brazil: an ecological approach regarding the large marine ecosystems. Ocean \& Coastal Management 76:96-104. https://doi.org/10.1016/j.ocecoaman.2013.02.003

Siar, S. V., and D. C. Kalikoski, editors. 2016. Strengthening organizations and collective action in fisheries: towards the formulation of a capacity development programme; workshop report and case studies, 4-6 November 2014, Barbados. FAO Fisheries and Aquaculture Proceedings No. 41. Food and Agriculture Organization of the United Nations, Rome, Italy.

Silva, M. R. O., and P. F. M. Lopes. 2015. Each fisherman is different: taking the environmental perception of small-scale fishermen into account to manage marine protected areas. Marine Policy 51:347-355. https://doi.org/10.1016/j.marpol.2014.09.019

Soares, H. C., D. F. M. Gherardi, L. P. Pezzi, M. T. Kayano, and E. T. Paes. 2014. Patterns of interannual climate variability in large marine ecosystems. Journal of Marine Systems 134:57-68. https://doi.org/10.1016/j.jmarsys.2014.03.004

Spalding, M. D., H. E. Fox, G. R. Allen, N. Davidson, Z. A. Ferdaña, M. Finlayson, B. S. Halpern, M. A. Jorge, A. Lombana, S. A. Lourie, K. D. Martin, E. McManus, J. Molnar, C. A. Recchia, and J. Robertson. 2007. Marine ecoregions of the world: a bioregionalization of coastal and shelf areas. BioScience 57 (7):573-583. https://doi.org/10.1641/B570707

Spiegelhalter, D. J., N. G. Best, B. P. Carlin, and A. Van Der Linde. 2002. Bayesian measures of model complexity and fit. Journal of the Royal Statistical Society: Series B (Statistical Methodology) 64(4):583-639. https://doi.org/10.1111/1467-9868.00353 
Steffen, W., Å. Persson, L. Deutsch, J. Zalasiewicz, M. Williams, K. Richardson, C. Crumley, P. Crutzen, C. Folke, L. Gordon, M. Molina, V. Ramanathan, J. Rockström, M. Scheffer, H. J. Schellnhuber, and U. Svedin. 2011. The Anthropocene: from global change to planetary stewardship. Ambio: A Journal of the Human Environment 40:739-761. https://doi.org/10.1007/ $\underline{\mathrm{s} 13280-011-0185-\mathrm{x}}$

Sunday, J. M., G. T. Pecl, S. Frusher, A. J. Hobday, N. Hill, N. J. Holbrook, G. J. Edgar, R. Stuart-Smith, N. Barret, T. Wernberg, R. A. Watson, D. A. Smale, E. A. Fulton, D. Slawinki, M. Feng, B. T. Radford, P. A. Thompson, and A. E. Bates. 2015. Species traits and climate velocity explain geographic range shifts in an ocean-warming hotspot. Ecology Letters 18(9):944-953. https:// doi.org/10.1111/ele.12474

Swanson, D. A., J. C. Hiley, H. D. Venema, and R. Grosshans. 2009. Indicators of adaptive capacity to climate change for agriculture in the prairie region of Canada: comparison with field observations. International Institute for Sustainable Development, Winnipeg, Manitoba, Canada.

Teh, L. C. L., and U. R. Sumaila. 2013. Contribution of marine fisheries to worldwide employment. Fish and Fisheries 14 (1):77-88. https://doi.org/10.1111/j.1467-2979.2011.00450.x

Teixeira-Neves, T. P., L. M. Neves, and F. G. Araújo. 2015. Hierarchizing biological, physical and anthropogenic factors influencing the structure of fish assemblages along tropical rocky shores in Brazil. Environmental Biology of Fishes 98(6):1645-1657. https://doi.org/10.1007/s10641-015-0390-8

Tschakert, P., B. van Oort, A. L. St. Clair, and A. LaMadrid. 2013. Inequality and transformation analyses: a complementary lens for addressing vulnerability to climate change. Climate and Development 5(4):340-350. https://doi.org/10.1080/17565529.2013.828583

Tyberghein, L., H. Verbruggen, K. Pauly, C. Troupin, F. Mineur, and O. De Clerck. 2012. Bio-ORACLE: a global environmental dataset for marine species distribution modelling. Global Ecology and Biogeography 21:272-281. https://doi.org/10.1111/ j.1466-8238.2011.00656.X

Veron, S., C. Penone, P. Clergeau, G. C. Costa, B. F. Oliveira, V. A. São-Pedro, and S. Pavoine. 2016. Integrating data-deficient species in analyses of evolutionary history loss. Ecology and Evolution 6(23):8502-8514. https://doi.org/10.1002/ece3.2390

Watanabe, S. 2010. Asymptotic equivalence of Bayes cross validation and widely applicable information criterion in singular learning theory. Journal of Machine Learning Research 11:3571-3594.

Welch, D. J., T. Saunders, J. Robins, A. Harry, J. Johnson, J. Maynard, R. Saunders, G. Pecl, B. Sawynok, and A. Tobin. 2014. Implications of climate change impacts on fisheries resources of northern Australia. Part 1: vulnerability assessment and adaptation options. FRDC Project 2010/565. James Cook University, Townsville, Queensland, Australia.

Whitney, C. K., N. J. Bennett, N. C. Ban, E. H. Allison, D. Armitage, J. L. Blythe, J. M. Burt, W. Cheung, E. M. Finkbeiner, M. Kaplan-Hallam, I. Perry, N. J. Turner, and L. Yumagulova. 2017. Adaptive capacity: from assessment to action in coastal social-ecological systems. Ecology and Society 22(2):22. http://dx. doi.org/10.5751/ES-09325-220222

World Wildlife Fund (WWF). 2016. Situação e tendências da pesca marítima no Brasile o papel dos subsídios. WWF, São Paulo, Brasil. 
Appendix 1. Sensitivity analyses.

Given that the decisions taken in the process of weighing the indicators equally could be unclear, we ran a sensitivity analysis to check the robustness of our findings. A sensitivity analysis is a repeat of the primary analysis but uses alternative decisions (or weights) to check uncertainty in the output of a mathematical model (Deeks et al. 2008, Nardo et al. 2008). It is also used to prove that the findings are not dependent on arbitrary decisions.

We chose four weighting schemes to check how each component contributes to estimating index values. In addition to assigning the same weight to the three components (equal weight), we also calculated the index by emphasizing one dimension at a time. We did that by assigning a $1 / 2$ weight to the emphasized component and $1 / 4$ to the remaining two. This alternative was run three times: once for each emphasized component. Although the weight variations changed index values (Table A3.1), rankings of the coastal states where the index was tested were very similar. In other words, looking at the most and least vulnerable coastal states across weighting schemes, the states of $\mathrm{CE}, \mathrm{AP}$, and $\mathrm{RN}$ are among the most vulnerable and the states of $\mathrm{AL}, \mathrm{PR}$, and PA are the least vulnerable. 
Table A1.1: Components and index values in the weighting scheme: equal weight (same weight among components), Emphasis AC (AC component weighing 1/2 and the other two weighing 1/4), Emphasis SP (SP component weighing $1 / 2$ and the other two weighing 1/4), and Emphasis ECO (ECO component weighing $1 / 2$ and the other two weighing $1 / 4$ ). AC = Adaptive capacity; $\mathrm{SP}=$ Species vulnerability; $\mathrm{ECO}=$ Ecosystem vulnerability; ICV = Index of Coastal Vulnerability. Highlighting the most vulnerable states (italic) and the least vulnerable states (bold).

\begin{tabular}{cccccccc}
\hline & \multicolumn{3}{c}{ Components } & \multicolumn{4}{c}{ ICV values } \\
\hline States & AC & SP & ECO & $\begin{array}{c}\text { Equal } \\
\text { weight }\end{array}$ & $\begin{array}{c}\text { Emphasis } \\
\text { AC }\end{array}$ & $\begin{array}{c}\text { Emphasis } \\
\text { SP }\end{array}$ & $\begin{array}{c}\text { Emphasis } \\
\text { ECO }\end{array}$ \\
\hline Amapá (AP) & 0.51 & 0.59 & 0.80 & 0.98 & 0.095 & 0.369 & 0.421 \\
Pará (PA) & 0.83 & 0.60 & 0.80 & $\mathbf{0 . 6 3}$ & $\mathbf{- 0 . 0 6 4}$ & $\mathbf{0 . 2 9 1}$ & $\mathbf{0 . 3 4 3}$ \\
Maranhão (MA) & 0.82 & 0.54 & 0.90 & $\mathbf{0 . 6 8}$ & $\mathbf{- 0 . 0 5 1}$ & $\mathbf{0 . 2 8 8}$ & $\mathbf{0 . 3 7 9}$ \\
Piauí (PI) & 0.83 & 0.58 & 0.96 & 0.79 & -0.029 & 0.321 & 0.418 \\
Ceará (CE) & 0.71 & 0.63 & 0.98 & 1.00 & 0.049 & 0.381 & 0.470 \\
Rio Grande do Norte (RN) & 0.64 & 0.51 & 0.98 & 0.94 & 0.053 & 0.340 & 0.458 \\
Paraíba (PB) & 0.53 & 0.59 & 0.60 & 0.73 & 0.033 & 0.313 & 0.315 \\
Pernambuco (PE) & 0.50 & 0.57 & 0.60 & 0.74 & 0.041 & 0.308 & 0.316 \\
Alagoas (AL) & 0.82 & 0.51 & 0.60 & $\mathbf{0 . 3 3}$ & $\mathbf{- 0 . 1 3 0}$ & $\mathbf{0 . 2 0 1}$ & $\mathbf{0 . 2 2 4}$ \\
Sergipe (SE) & 0.64 & 0.48 & 0.98 & 0.91 & 0.046 & 0.324 & 0.450 \\
Bahia (BA) & 0.70 & 0.50 & 0.99 & 0.88 & 0.024 & 0.323 & 0.444 \\
Espírito Santo (ES) & 0.74 & 0.50 & 0.96 & 0.81 & -0.003 & 0.306 & 0.421 \\
Rio de Janeiro (RJ) & 0.88 & 0.60 & 0.97 & 0.77 & -0.048 & 0.323 & 0.415 \\
São Paulo (SP) & 0.83 & 0.62 & 0.84 & $\mathbf{0 . 7 0}$ & $\mathbf{- 0 . 0 4 9}$ & $\mathbf{0 . 3 1 1}$ & $\mathbf{0 . 3 6 8}$ \\
Paraná (PR) & 0.74 & 0.40 & 0.90 & $\mathbf{0 . 6 1}$ & $\mathbf{- 0 . 0 4 8}$ & $\mathbf{0 . 2 3 6}$ & $\mathbf{0 . 3 6 1}$ \\
Santa Catarina (SC) & 0.64 & 0.53 & 0.90 & 0.87 & 0.038 & 0.328 & 0.420 \\
Rio Grande do Sul (RS) & 0.88 & 0.62 & 0.85 & $\mathbf{0 . 6 5}$ & $\mathbf{- 0 . 0 7 3}$ & $\mathbf{0 . 3 0 0}$ & $\mathbf{0 . 3 5 8}$ \\
\hline
\end{tabular}

\section{REFERENCES}

Deeks, J. J., J. P. Higgins, and D. G. Altman. 2008. Analysing data and undertaking metaanalyses. Cochrane handbook for systematic reviews of interventions: Cochrane book series, 243-296.

Nardo, M., and M. Saisana. 2008. OECD/JRC handbook on constructing composite indicators. Putting theory into practice. 
Appendix 2. Target species in all 17 states analyzed along the Brazilian coastline with their vulnerability variables.

Table A2.1: Target species in all 17 states analyzed along the Brazilian coastline with their vulnerability variables. Information is described for each species of the 10 main fish targets in weight by artisanal and industrial sectors. FP = fishing pressure, $\mathrm{SS}=$ stock status, ThoL $=$ trophic level, $\mathrm{RES}=$ resilience, $\mathrm{VUL}=$ vulnerability, $\mathrm{TheL}=$ Threat level, $\mathrm{PC}=$ price category, $\mathrm{DR}=$ distribution range, art $=$ artisanal, ind $=$ industrial, mod $=$ moderate, $\mathrm{vul}=$ vulnerable, $\mathrm{lc}=$ least concern, $\mathrm{nt}=$ near threatened, not $=$ not threat, $\mathrm{dd}=$ data deficient.

\begin{tabular}{|c|c|c|c|c|c|c|c|c|c|}
\hline STATES & SPECIES & FP & SS & ThoL & RES & VUL & TheL & $\mathrm{PC}$ & DR \\
\hline AP & Sciades parkeri & ind/art & overexploited & 4.1 & High & high & vul & medium & Western_Atlantic \\
\hline AP & Cynoscion acoupa & ind/art & exploited & 4.1 & medium & high & lc & medium & Western_Atlantic \\
\hline AP & Sciades couma & ind/art & exploited & 3.9 & medium & $\bmod$ & lc & medium & South_America \\
\hline AP & Coryphaena hippurus & art & exploited & 4.4 & High & $\bmod$ & lc & high & Atlantic_Indian_Pacific \\
\hline AP & Micropogonias furnieri & art & exploited & 3.1 & medium & $\bmod$ & lc & medium & Western_Atlantic \\
\hline AP & Sciades proops & art & exploited & 4.4 & High & $\bmod$ & na & medium & WesternAtlantic \\
\hline AP & Cynoscion virescens & art & overexploited & 4 & Low & high & lc & medium & WesternAtlantic \\
\hline AP & Megalops atlanticus & art & rebuilding & 4.5 & Low & very high & vul & medium & Atlantic_Pacific \\
\hline AP & Bagre bagre & art & exploited & 4 & Low & high & lc & medium & South_America \\
\hline AP & Lutjanus purpureus & ind/art & overexploited & 3.6 & Low & high & vul & high & WesternAtlantic \\
\hline PA & Cynoscion acoupa & ind/art & exploited & 4.1 & medium & high & lc & medium & Western_Atlantic \\
\hline PA & Sciades parkeri & art & overexploited & 4.1 & High & high & vul & medium & Western_Atlantic \\
\hline PA & Scomberomorus brasiliensis & art & exploited & 3.3 & medium & very high & lc & high & Western_Atlantic \\
\hline PA & Lutjanus purpureus & ind/art & overexploited & 3.6 & Low & high & vul & high & WesternAtlantic \\
\hline PA & Sciades proops & art & exploited & 4.4 & High & $\bmod$ & na & medium & WesternAtlantic \\
\hline PA & Cynoscion microlepidotus & art & exploited & 4 & Low & high & lc & medium & WesternAtlantic \\
\hline PA & Sciades herzbergii & art & overexploited & 3.3 & medium & $\bmod$ & lc & medium & South_America \\
\hline PA & Macrodon ancylodon & ind/art & exploited & 3.9 & medium & $\bmod$ & lc & medium & WesternAtlantic \\
\hline PA & Coryphaena hippurus & art & exploited & 4.4 & High & $\bmod$ & lc & high & Atlantic_Indian_Pacific \\
\hline PA & Sciades couma & ind & exploited & 3.9 & medium & $\bmod$ & lc & medium & South_America \\
\hline MA & Cynoscion acoupa & art & exploited & 4.1 & medium & high & lc & medium & Western_Atlantic \\
\hline MA & Macrodon ancylodon & art & exploited & 3.9 & medium & $\bmod$ & lc & medium & WesternAtlantic \\
\hline MA & Hexanematichthys herzbergii & art & overexploited & 3.3 & medium & $\bmod$ & lc & medium & South_America \\
\hline
\end{tabular}




\begin{tabular}{|c|c|c|c|c|c|c|c|c|c|}
\hline MA & Scomberomorus brasiliensis & art & exploited & 3.3 & medium & very high & lc & high & Western_Atlantic \\
\hline MA & Aspistor quadriscutis & art & exploited & 3.5 & medium & $\bmod$ & lc & medium & South_America \\
\hline MA & Micropogonias furnieri & art & exploited & 3.1 & medium & $\bmod$ & lc & medium & Western_Atlantic \\
\hline MA & Sciades proops & art & exploited & 4.4 & High & $\bmod$ & na & medium & WesternAtlantic \\
\hline MA & Bagre bagre & art & exploited & 4 & Low & high & lc & medium & South_America \\
\hline MA & Cynoscion leiarchus & art & overexploited & 3.1 & medium & $\bmod$ & lc & medium & WesternAtlantic \\
\hline MA & Genyatremus luteus & art & overexploited & 3.5 & medium & $\bmod$ & $\mathrm{dd}$ & medium & WesternAtlantic \\
\hline PI & Lutjanus synagris & art & exploited & 3.8 & medium & $\bmod$ & $\mathrm{nt}$ & medium & WesternAtlantic \\
\hline PI & Scomberomorus brasiliensis & art & exploited & 3.3 & medium & very high & lc & high & Western_Atlantic \\
\hline PI & Scomberomorus cavalla & art & exploited & 4.4 & Low & high & lc & medium & $\begin{array}{l}\text { WesternAtlantic_EasternCentral } \\
\text { Atlantic }\end{array}$ \\
\hline PI & Euthynnus alletteratus & art & exploited & 4.5 & medium & high & lc & medium & Atlantic \\
\hline PI & Ocyurus chrysurus & art & exploited & 4 & Low & high & dd & medium & $\begin{array}{l}\text { WesternAtlantic_EasternCentral } \\
\text { Atlantic }\end{array}$ \\
\hline PI & Lutjanus purpureus & art & overexploited & 3.6 & Low & high & vul & high & WesternAtlantic \\
\hline PI & Micropogonias furnieri & art & exploited & 3.1 & medium & $\bmod$ & lc & medium & Western_Atlantic \\
\hline PI & Conodon nobilis & art & overexploited & 3.6 & medium & $\bmod$ & lc & low & $\begin{array}{l}\text { WesternAtlantic_WesternGulfof } \\
\text { Mexico }\end{array}$ \\
\hline PI & Chloroscombrus chrysurus & art & exploited & 3.5 & medium & $\bmod$ & lc & low & WesternAtlantic_EasternAtlantic \\
\hline PI & Lycengraulis grossidens & art & exploited & 3.7 & medium & $\bmod$ & lc & medium & WesternAtlantic \\
\hline $\mathrm{CE}$ & Ocyurus chrysurus & art & exploited & 4 & Low & high & $\mathrm{dd}$ & medium & $\begin{array}{l}\text { WesternAtlantic_EasternCentral } \\
\text { Atlantic }\end{array}$ \\
\hline $\mathrm{CE}$ & Opisthonema oglinum & art & exploited & 4.5 & medium & low & lc & medium & WesternAtlantic \\
\hline $\mathrm{CE}$ & Scomberomorus cavalla & ind/art & exploited & 4.4 & Low & high & lc & medium & $\begin{array}{l}\text { WesternAtlantic_EasternCentral } \\
\text { Atlantic }\end{array}$ \\
\hline $\mathrm{CE}$ & Lutjanus synagris & art & exploited & 3.8 & medium & $\bmod$ & nt & medium & WesternAtlantic \\
\hline $\mathrm{CE}$ & Scomberomorus brasiliensis & art & exploited & 3.3 & medium & very high & lc & high & Western_Atlantic \\
\hline $\mathrm{CE}$ & Haemulon plumierii & art & exploited & 3.8 & medium & high & lc & medium & Western_Atlantic \\
\hline
\end{tabular}




\begin{tabular}{|c|c|c|c|c|c|c|c|c|c|}
\hline $\mathrm{CE}$ & Chloroscombrus chrysurus & art & exploited & 3.5 & medium & $\bmod$ & lc & low & WesternAtlantic_EasternAtlantic \\
\hline $\mathrm{CE}$ & Carangoides bartholomaei & art & exploited & 4.5 & High & high & lc & medium & $\begin{array}{l}\text { Western_EasternCentral_Atlanti } \\
\mathrm{c}\end{array}$ \\
\hline $\mathrm{CE}$ & Mycteroperca bonaci & art & overexploited & 4.3 & Low & high & vul & very high & Western_Atlantic \\
\hline $\mathrm{CE}$ & Lutjanus purpureus & ind/art & overexploited & 3.6 & Low & high & vul & high & WesternAtlantic \\
\hline $\mathrm{RN}$ & Xiphias gladius & ind & exploited & 4.5 & medium & very high & lc & very high & Atlantic_Indian_Pacific \\
\hline $\mathrm{RN}$ & Thunnus albacares & ind/art & exploited & 4.4 & medium & high & nt & high & Worldwide \\
\hline $\mathrm{RN}$ & Opisthonema oglinum & art & exploited & 4.5 & medium & low & lc & medium & WesternAtlantic \\
\hline $\mathrm{RN}$ & Hirundichthys affinis & art & overexploited & 3.8 & High & low & lc & medium & $\begin{array}{l}\text { Eastern_Western_NorthwestAtla } \\
\text { ntic }\end{array}$ \\
\hline $\mathrm{RN}$ & Thunnus obesus & ind & overexploited & 4.5 & medium & high & vul & very high & Atlantic_Indian_Pacific \\
\hline $\mathrm{RN}$ & Scomberomorus brasiliensis & art & exploited & 3.3 & medium & very high & lc & high & Western_Atlantic \\
\hline $\mathrm{RN}$ & Prionace glauca & ind & exploited & 4.4 & very low & very high & $\mathrm{nt}$ & medium & Circumglobal_Atlantic_Pacific \\
\hline $\mathrm{RN}$ & Xyrichtys novacula & art & overexploited & 3.5 & medium & $\bmod$ & lc & very high & Western_Eastern_Atlantic \\
\hline $\mathrm{RN}$ & Haemulon plumierii & art & exploited & 3.8 & medium & high & lc & medium & Western_Atlantic \\
\hline $\mathrm{RN}$ & Ocyurus chrysurus & art & exploited & 4 & Low & high & $\mathrm{dd}$ & medium & $\begin{array}{l}\text { WesternAtlantic_EasternCentral } \\
\text { Atlantic }\end{array}$ \\
\hline PB & Thunnus albacares & ind & exploited & 4.4 & medium & high & nt & high & Worldwide \\
\hline PB & Thunnus obesus & ind & overexploited & 4.5 & medium & high & vul & very high & Atlantic_Indian_Pacific \\
\hline PB & Xiphias gladius & ind & exploited & 4.5 & medium & very high & lc & very high & Atlantic_Indian_Pacific \\
\hline PB & Thunnus alalunga & ind & overexploited & 4.3 & medium & high & $\mathrm{nt}$ & high & $\begin{array}{l}\text { Cosmopolitan_tropical_temperat } \\
\mathrm{e}\end{array}$ \\
\hline PB & Prionace glauca & ind & exploited & 4.4 & very low & very high & $\mathrm{nt}$ & medium & Circumglobal_Atlantic_Pacific \\
\hline PB & Mugil curema & art & collapsed & 2 & medium & high & lc & medium & $\begin{array}{l}\text { Western_EasternAtlantic_Easter } \\
\text { nPacific }\end{array}$ \\
\hline
\end{tabular}




\begin{tabular}{|c|c|c|c|c|c|c|c|c|c|}
\hline PB & Istiophorus platypterus & ind & overexploited & 4.5 & Low & very high & lc & very high & $\begin{array}{l}\text { Worldwide_IndoPacific_Eastern } \\
\text { Pacific_Indian }\end{array}$ \\
\hline PB & Centropomus undecimalis & art & exploited & 4.2 & medium & high & lc & Low & Western_Atlantic \\
\hline PB & Trachinotus falcatus & art & overexploited & 4 & medium & $\bmod$ & lc & medium & Western_Atlantic \\
\hline PB & Scomberomorus brasiliensis & art & exploited & 3.3 & medium & very high & lc & High & Western_Atlantic \\
\hline PE & Anchovia clupeoides & art & exploited & 3.4 & High & $\bmod$ & lc & medium & Western_Atlantic \\
\hline PE & Thunnus albacares & ind & exploited & 4.4 & medium & high & nt & High & Worldwide \\
\hline $\mathrm{PE}$ & Pseudupeneus maculatus & art & exploited & 3.7 & High & $\bmod$ & lc & medium & Western_Atlantic \\
\hline PE & Mugil curema & art & collapsed & 2 & medium & high & lc & medium & $\begin{array}{l}\text { Western_EasternAtlantic_Easter } \\
\text { nPacific }\end{array}$ \\
\hline PE & Opisthonema oglinum & art & exploited & 4.5 & medium & low & lc & medium & WesternAtlantic \\
\hline PE & Haemulon aurolineatum & art & rebuilding & 4.4 & medium & $\bmod$ & lc & medium & Western_Atlantic \\
\hline PE & Conodon nobilis & art & overexploited & 3.6 & medium & $\bmod$ & lc & low & $\begin{array}{l}\text { WesternAtlantic_WesternGulfof } \\
\text { Mexico }\end{array}$ \\
\hline PE & Sparisoma spp_axillare & art & exploited & 2 & medium & $\bmod$ & vul & na & Southwest_Atlantic_endemic \\
\hline $\mathrm{PE}$ & Lutjanus analis & art & exploited & 3.9 & Low & high & nt & high & Western_Atlantic \\
\hline $\mathrm{PE}$ & Acanthocybium solandri & ind & rebuilding & 4.3 & medium & high & lc & very high & Atlantic_Indian_Pacific \\
\hline AL & Mugil curvidens & art & exploited & 2 & medium & $\bmod$ & $\mathrm{nt}$ & na & Western_Atlantic \\
\hline $\mathrm{AL}$ & Opisthonema oglinum & art & exploited & 4.5 & medium & low & lc & medium & WesternAtlantic \\
\hline $\mathrm{AL}$ & Macrodon ancylodon & art & exploited & 3.9 & medium & $\bmod$ & lc & medium & WesternAtlantic \\
\hline AL & Caranx hippos & art & exploited & 3.6 & medium & $\bmod$ & lc & medium & Western_Eastern_Atlantic \\
\hline AL & Diapterus auratus & art & exploited & 2.4 & High & $\bmod$ & lc & medium & Western_Atlantic \\
\hline $\mathrm{AL}$ & Scomberomorus brasiliensis & art & exploited & 3.3 & medium & very high & lc & high & Western_Atlantic \\
\hline $\mathrm{AL}$ & Balistes vetula & art & rebuilding & 3.8 & medium & $\bmod$ & $\mathrm{nt}$ & medium & Western_Eastern_Atlantic \\
\hline $\mathrm{AL}$ & Scomberomorus cavalla & art & exploited & 4.4 & Low & high & lc & medium & $\begin{array}{l}\text { WesternAtlantic_EasternCentral } \\
\text { Atlantic }\end{array}$ \\
\hline
\end{tabular}




\begin{tabular}{|c|c|c|c|c|c|c|c|c|c|}
\hline $\begin{array}{l}\mathrm{AL} \\
\mathrm{AL}\end{array}$ & $\begin{array}{l}\text { Mugil liza } \\
\text { Sciades herzbergii }\end{array}$ & $\begin{array}{l}\text { art } \\
\text { art }\end{array}$ & $\begin{array}{l}\text { rebuilding } \\
\text { overexploited }\end{array}$ & $\begin{array}{l}2 \\
3.3 \\
\end{array}$ & $\begin{array}{l}\text { medium } \\
\text { medium }\end{array}$ & $\begin{array}{l}\bmod \\
\bmod \end{array}$ & $\begin{array}{l}\text { dd } \\
\text { lc }\end{array}$ & $\begin{array}{l}\text { high } \\
\text { medium }\end{array}$ & $\begin{array}{l}\text { Western_Atlantic } \\
\text { South_America }\end{array}$ \\
\hline SE & Mugil curema & art & collapsed & 2 & medium & high & lc & medium & $\begin{array}{l}\text { Western_EasternAtlantic_Easter } \\
\text { nPacific }\end{array}$ \\
\hline SE & Macrodon ancylodon & art & exploited & 3.9 & medium & $\bmod$ & lc & medium & WesternAtlantic \\
\hline SE & Sciades herzbergii & art & overexploited & 3.3 & medium & $\bmod$ & lc & medium & South_America \\
\hline SE & Anchoviella vaillanti & art & overexploited & 3.2 & High & low & nt & na & South_America \\
\hline SE & Caranx hippos & art & exploited & 3.6 & medium & $\bmod$ & lc & medium & Western_Eastern_Atlantic \\
\hline SE & Micropogonias furnieri & art & exploited & 3.1 & medium & $\bmod$ & lc & medium & Western_Atlantic \\
\hline SE & Diapterus rhombeus & art & overexploited & 3 & High & low & lc & medium & Western_Atlantic \\
\hline SE & Cathorops spixii & art & overexploited & 3.5 & medium & high & na & medium & Western_Atlantic \\
\hline SE & Scomberomorus cavalla & art & exploited & 4.4 & Low & high & lc & medium & $\begin{array}{l}\text { WesternAtlantic_EasternCentral } \\
\text { Atlantic }\end{array}$ \\
\hline SE & Conodon nobilis & art & overexploited & 3.6 & medium & mod & lc & low & $\begin{array}{l}\text { WesternAtlantic_WesternGulfof } \\
\text { Mexico }\end{array}$ \\
\hline BA & Sardinella brasiliensis & art & rebuilding & 3.1 & High & low & na & medium & Western_Atlantic \\
\hline BA & Ocyurus chrysurus & art & exploited & 4 & Low & high & dd & medium & $\begin{array}{l}\text { WesternAtlantic_EasternCentral } \\
\text { Atlantic }\end{array}$ \\
\hline BA & Opisthonema oglinum & art & exploited & 4.5 & medium & low & lc & medium & WesternAtlantic \\
\hline BA & Diapterus rhombeus & art & overexploited & 3 & High & low & lc & medium & Western_Atlantic \\
\hline BA & Cetengraulis edentulus & art & rebuilding & 2.1 & medium & $\bmod$ & lc & medium & Western_Atlantic \\
\hline BA & Lutjanus jocu & art & exploited & 4.4 & Low & very high & $\mathrm{dd}$ & high & Western_Eastern_Atlantic \\
\hline BA & Coryphaena hippurus & art & exploited & 4.4 & High & $\bmod$ & lc & high & Atlantic_Indian_Pacific \\
\hline BA & Mycteroperca spp_bonaci & art & overexploited & 4.3 & Low & high & vul & very high & Western_Atlantic \\
\hline BA & Caranx crysos & art & exploited & 4.1 & medium & $\bmod$ & lc & low & Western_Eastern_Atlantic \\
\hline
\end{tabular}




\begin{tabular}{|c|c|c|c|c|c|c|c|c|c|}
\hline BA & Pomacanthus paru & ind & exploited & 2.8 & medium & $\bmod$ & lc & high & Western_Eastern_Atlantic \\
\hline ES & Coryphaena hippurus & art & exploited & 4.4 & High & $\bmod$ & lc & high & Atlantic_Indian_Pacific \\
\hline $\mathrm{ES}$ & Balistes capriscus & art & overexploited & 4.1 & medium & high & vul & high & Western_Eastern_Atlantic \\
\hline ES & Thunnus albacares & ind/art & exploited & 4.4 & medium & high & nt & high & Worldwide \\
\hline $\mathrm{ES}$ & Ocyurus chrysurus & art & exploited & 4 & Low & high & $\mathrm{dd}$ & medium & $\begin{array}{l}\text { WesternAtlantic_EasternCentral } \\
\text { Atlantic }\end{array}$ \\
\hline ES & Trachurus lathami & ind & rebuilding & 4 & medium & $\bmod$ & lc & low & Western_Atlantic \\
\hline ES & Pagrus pagrus & art & rebuilding & 3.9 & medium & very high & lc & very high & Western_Eastern_Atlantic \\
\hline ES & Caranx crysos & ind & exploited & 4.1 & medium & $\bmod$ & lc & low & Western_Eastern_Atlantic \\
\hline $\mathrm{ES}$ & Katsuwonus pelamis & ind & exploited & 4.4 & medium & $\bmod$ & lc & high & $\begin{array}{l}\text { Cosmopolitan_tropical_warmte } \\
\text { mperate }\end{array}$ \\
\hline ES & Lutjanus purpureus & art & overexploited & 3.6 & Low & high & vul & high & WesternAtlantic \\
\hline ES & Coryphaena hippurus & ind & exploited & 4.4 & High & $\bmod$ & lc & high & Atlantic_Indian_Pacific \\
\hline $\mathrm{RJ}$ & Sardinella brasiliensis & ind/art & rebuilding & 3.1 & High & low & na & medium & Western_Atlantic \\
\hline RJ & Cetengraulis edentulus & ind & rebuilding & 2.1 & medium & $\bmod$ & lc & medium & Western_Atlantic \\
\hline RJ & Katsuwonus pelamis & art & exploited & 4.4 & medium & $\bmod$ & lc & high & $\begin{array}{l}\text { Cosmopolitan_tropical_warmte } \\
\text { mperate }\end{array}$ \\
\hline RJ & Stephanolepis hispidus & art & collapsed & 2.6 & High & $\bmod$ & lc & na & Western_Eastern_Atlantic \\
\hline RJ & Scomber colias & ind/art & collapsed & 3.9 & medium & $\bmod$ & lc & na & Atlantic \\
\hline RJ & Micropogonias furnieri & ind & exploited & 3.1 & medium & $\bmod$ & lc & medium & Western_Atlantic \\
\hline RJ & Caranx latus & ind & exploited & 4.2 & medium & high & lc & high & Western_Eastern_Atlantic \\
\hline $\mathrm{RJ}$ & Thunnus albacares & ind & exploited & 4.4 & medium & high & nt & high & Worldwide \\
\hline RJ & Opisthonema oglinum & ind & exploited & 4.5 & medium & low & lc & medium & WesternAtlantic \\
\hline
\end{tabular}




\begin{tabular}{|c|c|c|c|c|c|c|c|c|c|}
\hline RJ & Lophius gastrophysus & ind & overexploited & 4.5 & medium & high & lc & low & WesternAtlantic \\
\hline SP & Sardinella brasiliensis & ind/art & rebuilding & 3.1 & High & low & na & medium & Western_Atlantic \\
\hline SP & Micropogonias furnieri & ind/art & exploited & 3.1 & medium & $\bmod$ & $\mathrm{lc}$ & medium & Western_Atlantic \\
\hline SP & Cynoscion jamaicensis & ind & overexploited & 3.8 & High & low & lc & medium & Western_Atlantic \\
\hline SP & Anchoviella lepidentostole & art & exploited & 3.1 & High & low & lc & medium & Western_Atlantic \\
\hline SP & Macrodon atricauda & ind/art & overexploited & 4 & High & low & na & na & Southwest_Atlantic \\
\hline SP & Scomber colias & ind & collapsed & 3.9 & medium & $\bmod$ & lc & na & Atlantic \\
\hline SP & Lophius gastrophysus & ind & overexploited & 4.5 & medium & high & lc & low & WesternAtlantic \\
\hline SP & Xiphias gladius & ind & exploited & 4.5 & medium & very high & lc & very high & Atlantic_Indian_Pacific \\
\hline SP & Mugil liza & ind/art & rebuilding & 2 & medium & $\bmod$ & $\mathrm{dd}$ & High & Western_Atlantic \\
\hline SP & Coryphaena hippurus & art & exploited & 4.4 & High & $\bmod$ & lc & High & Atlantic_Indian_Pacific \\
\hline PR & Sardinella brasiliensis & art & rebuilding & 3.1 & High & low & na & medium & Western_Atlantic \\
\hline PR & Harengula clupeola & art & overexploited & 3.3 & High & low & lc & low & Western_Atlantic \\
\hline PR & Chloroscombrus chrysurus & art & exploited & 3.5 & medium & $\bmod$ & lc & low & WesternAtlantic_EasternAtlantic \\
\hline PR & Micropogonias furnieri & art & exploited & 3.1 & medium & $\bmod$ & lc & medium & Western_Atlantic \\
\hline PR & Opisthonema oglinum & art & exploited & 4.5 & medium & low & lc & medium & WesternAtlantic \\
\hline PR & Cynoscion virescens & art & overexploited & 4 & Low & high & lc & medium & WesternAtlantic \\
\hline PR & Oligoplites saurus_saliens & art & $\begin{array}{l}\text { collapsed/rebuild } \\
\text { ing }\end{array}$ & 4.05 & High & $\bmod$ & lc & medium & $\begin{array}{l}\text { WesternAtlantic_EasternPacific } \\
\text { _WesternAtlantic }\end{array}$ \\
\hline PR & Pogonias cromis & art & collapsed & 3.9 & medium & high & vul & low & WesternAtlantic \\
\hline PR & Macrodon atricauda & art & overexploited & 4 & High & low & na & na & Southwest_Atlantic \\
\hline PR & Mugil liza & art & rebuilding & 2 & medium & $\bmod$ & dd & high & Western_Atlantic \\
\hline $\mathrm{SC}$ & Sardinella brasiliensis & ind/art & rebuilding & 3.1 & High & low & na & medium & Western_Atlantic \\
\hline $\mathrm{SC}$ & Katsuwonus pelamis & ind & exploited & 4.4 & medium & $\bmod$ & lc & high & $\begin{array}{l}\text { Cosmopolitan_tropical_warmte } \\
\text { mperate }\end{array}$ \\
\hline $\mathrm{SC}$ & Micropogonias furnieri & ind/art & exploited & 3.1 & medium & $\bmod$ & lc & medium & Western_Atlantic \\
\hline $\mathrm{SC}$ & Opisthonema oglinum & ind & exploited & 4.5 & medium & low & lc & medium & WesternAtlantic \\
\hline
\end{tabular}




\begin{tabular}{|c|c|c|c|c|c|c|c|c|c|}
\hline $\mathrm{SC}$ & Umbrina canosai & ind & exploited & 3.9 & medium & mod & na & low & Southwest_Atlantic \\
\hline SC & Prionotus punctatus & ind & exploited & 3.8 & Low & high & lc & medium & WesternAtlantic \\
\hline SC & Urophycis mystacea & ind & exploited & 4 & Low & high & na & na & Southwest_Atlantic \\
\hline $\mathrm{SC}$ & Cynoscion guatucupa & ind & exploited & 3.7 & medium & mod & na & na & Southwest_Atlantic \\
\hline $\mathrm{SC}$ & Chloroscombrus chrysurus & ind & exploited & 3.5 & medium & mod & lc & low & WesternAtlantic_EasternAtlantic \\
\hline $\mathrm{SC}$ & Mugil liza & ind/art & rebuilding & 2 & medium & mod & dd & high & Western_Atlantic \\
\hline RS & Micropogonias furnieri & ind/art & exploited & 3.1 & medium & mod & lc & medium & Western_Atlantic \\
\hline RS & Umbrina canosai & & exploited & 3.9 & medium & mod & na & low & Southwest_Atlantic \\
\hline RS & Cynoscion guatucupa & ind/art & exploited & 3.7 & medium & $\bmod$ & na & na & Southwest_Atlantic \\
\hline $\mathrm{RS}$ & Katsuwonus pelamis & ind & exploited & 4.4 & medium & mod & lc & high & $\begin{array}{l}\text { Cosmopolitan_tropical_warmte } \\
\text { mperate }\end{array}$ \\
\hline RS & Macrodon atricauda & ind & overexploited & 4 & High & low & na & na & Southwest_Atlantic \\
\hline RS & Prionotus punctatus & art & exploited & 3.8 & Low & high & lc & medium & WesternAtlantic \\
\hline RS & Pomatomus saltatrix & ind & collapsed & 4.5 & medium & high & vul & very high & $\begin{array}{l}\text { Circumglobal_Atlantic_Indian_ } \\
\text { Pacific }\end{array}$ \\
\hline RS & Mugil liza & ind/art & rebuilding & 2 & medium & mod & $\mathrm{dd}$ & high & Western_Atlantic \\
\hline RS & Urophycis brasiliensis & ind & exploited & 3.8 & medium & $\bmod$ & na & low & Southwest_Atlantic \\
\hline RS & Thunnus albacares & ind & exploited & 4.4 & medium & high & $\mathrm{nt}$ & high & Worldwide \\
\hline
\end{tabular}


Appendix 3. Measuring the fisheries instability indicator.

This indicator was based on resilience levels of an ecosystem function to environmental perturbations (see Oliver et al. 2015). In the context used here, we referred to the tendency of fisheries provision to remain stable in the face of some perturbation and rapidly return to pre-perturbation levels. This instability was estimated to be the total deficit of the ecosystem function in time. To measure this deficit, we calculated the annual instability by attributing one point for each year that catch data were provided below the minimum threshold (inferior quantile of the time series), plus the difference between the minimum threshold and annual catch, as follows:

$$
\text { Annual Instability }=1+(\text { minimum threshold }- \text { annual catch })
$$

The minimum threshold represents a measure of resistance of ecosystem function to perturbation, while the annual catch represents a recovery measure (Oliver et al. 2015). Annual instability values were calculated for time series and averaged for each coastal state. We used Z-transformations for both data normalization and to reduce the variability among states (Zuur et al. 2010).

\section{REFERENCES}

Oliver, T. H., M. S. Heard, N. J. B. Isaac, D. B. Roy, D. Procter, F. Eigenbrod, R. Frecjleton, A. Hector, C. D. L. Orme, O. L. Petchey, V. Proença, D. Rafaelli, K. B. Suttle, G. M. Mace, B. Marín-López, B. A. Woodcock, and J. M. Bullock. 2015. Biodiversity and resilience of ecosystem functions. Trends in ecology \& evolution, 30(11), 673-684.

Zuur, A. F., Ieno, E. N., and C. S. Elphick. 2010. A protocol for data exploration to avoid common statistical problems. Methods in ecology and evolution, 1(1), 3-14. 
Appendix 4. Measuring market indicator.

To assess coastal-urban integration, we used the linear distance between each coastal municipality and its respective state capital. Based on the walking distance from Google Maps, we calculated the average distance for all coastal municipalities, by state. This measure was used to represent an economic concern for fishers. Given the poor local transportation infrastructure, urban access can be used as a proxy for external transaction commerce costs (Davidova et al. 2009, Basurto et al. 2013). Even if fish value chains are networks with non-linear movements, for the sake of simplicity we assumed that longer distances to the urban center may imply fewer exploitation rates due to higher costs and, thereby, result in less ecological vulnerability to the SES. Moreover, we used per capita fish consumption (KG/Inhabitant/Year) because higher consumption implies more fish biomass required, which increases the system's vulnerability. We know that higher consumption could also be associated with cultural or economic issues, but we chose to focus on the consumption/demand for fish and not necessarily for a market analysis. Even if the linear distance and the per capita consumption adopted here are not the best variables, they are good proxies for fisheries demand in the absence of more refined data. Thus, these variables were combined to form a single market indicator that attempts to capture fisheries market demand in the coastal states.

\section{REFERENCES}

Basurto, X., A. Bennett, A. Hudson Weaver, S. Rodriguez-Van Dyck, and J.-S. AcevesBueno. 2013. Cooperative and noncooperative strategies for small-scale fisheries' selfgovernance in the globalization era: implications for conservation. Ecology and Society 18(4): 38. http://dx.doi.org/10.5751/ES-05673-180438

Davidova, S., L. Fredriksson, and A. Bailey. 2009. Subsistence and semi-subsistence farming in selected EU new member states. Agricultural Economics, 40, 733-744. 
Appendix 5. Indicator scores for the three components of the composite index, including all indicators.

Table A5.1: Indicator scores for the three components in all 17 Brazilian coastal states.

\begin{tabular}{|c|c|c|c|c|c|c|c|c|c|c|c|c|c|c|c|c|c|c|c|}
\hline \multirow[b]{2}{*}{ Components } & \multirow[b]{2}{*}{ Indicators } & \multicolumn{17}{|c|}{ Coastal States } & \multirow[b]{2}{*}{ Median } \\
\hline & & AP & PA & MA & PI & $\mathrm{CE}$ & RN & PB & $\mathrm{PE}$ & $\mathrm{AL}$ & SE & BA & ES & RJ & SP & PR & $\mathrm{SC}$ & $\mathrm{RS}$ & \\
\hline \multirow[t]{4}{*}{$\begin{array}{l}\text { Adaptive } \\
\text { Capacity }\end{array}$} & $\begin{array}{l}\text { Human } \\
\text { development index }\end{array}$ & 0.71 & 0.65 & 0.64 & 0.65 & 0.68 & 0.68 & 0.66 & 0.67 & 0.63 & 0.67 & 0.66 & 0.74 & 0.76 & 0.78 & 0.75 & 0.77 & 0.75 & 0.68 \\
\hline & $\begin{array}{l}\text { Educational } \\
\text { attainment }\end{array}$ & 0.30 & 0.30 & 1.00 & 1.00 & 0.60 & 0.60 & 1.00 & 0.60 & 1.00 & 0.60 & 0.60 & 0.60 & 0.30 & 0.30 & 0.60 & 0.30 & 0.30 & 0.60 \\
\hline & Governance & 0.87 & 1.00 & 0.40 & 0.30 & 0.73 & 0.40 & 0.40 & 0.40 & 0.40 & 0.40 & 0.73 & 0.73 & 1.00 & 0.87 & 0.73 & 0.50 & 1.00 & 0.73 \\
\hline & Social capital & 0.30 & 1.00 & 1.00 & 1.00 & 1.00 & 1.00 & 0.30 & 0.30 & 1.00 & 1.00 & 1.00 & 1.00 & 1.00 & 1.00 & 1.00 & 1.00 & 1.00 & 1.00 \\
\hline \multirow{8}{*}{$\begin{array}{l}\text { Species } \\
\text { Vulnerability }\end{array}$} & & 0.55 & 0.45 & 0.50 & 0.65 & 0.65 & 0.50 & 0.56 & 0.45 & 0.50 & 0.45 & 0.50 & 0.50 & 0.40 & 0.25 & 0.35 & 0.55 & 0.50 & 0.50 \\
\hline & Vulnerability & 0.80 & 0.75 & 0.65 & 0.75 & 0.80 & 0.75 & 0.95 & 0.65 & 0.55 & 0.55 & 0.50 & 0.75 & 0.55 & 0.40 & 0.40 & 0.50 & 0.60 & 0.65 \\
\hline & Price category & 0.60 & 0.65 & 0.55 & 0.50 & 0.60 & 0.75 & 0.75 & 0.61 & 0.61 & 0.44 & 0.65 & 0.75 & 0.63 & 0.63 & 0.39 & 0.50 & 0.63 & 0.61 \\
\hline & Threat level & 0.90 & 0.82 & 0.62 & 0.74 & 0.82 & 0.84 & 0.84 & 0.68 & 0.52 & 0.50 & 0.64 & 0.96 & 0.66 & 0.68 & 0.64 & 0.66 & 0.76 & 0.68 \\
\hline & Trophic level & 0.30 & 0.20 & 0.00 & 0.15 & 0.25 & 0.20 & 0.25 & 0.20 & 0.05 & 0.00 & 0.10 & 0.25 & 0.05 & 0.00 & 0.10 & 0.00 & 0.15 & 0.15 \\
\hline & Distribution range & 0.80 & 0.90 & 1.00 & 0.75 & 0.80 & 0.45 & 0.30 & 0.65 & 0.85 & 0.75 & 0.70 & 0.40 & 0.65 & 0.75 & 0.90 & 0.85 & 0.70 & 0.75 \\
\hline & Fishing pressure & 0.58 & 0.54 & 0.30 & 0.30 & 0.44 & 0.46 & 0.48 & 0.36 & 0.30 & 0.30 & 0.33 & 0.49 & 0.62 & 0.70 & 0.30 & 0.72 & 0.73 & 0.46 \\
\hline & Stock status & 0.53 & 0.52 & 0.52 & 0.48 & 0.48 & 0.52 & 0.62 & 0.52 & 0.46 & 0.66 & 0.50 & 0.50 & 0.58 & 0.60 & 0.64 & 0.42 & 0.51 & 0.52 \\
\hline \multirow[t]{5}{*}{$\begin{array}{l}\text { Ecosystem } \\
\text { Vulnerability }\end{array}$} & Climate exposure & 0.94 & 0.97 & 0.99 & 0.98 & 0.98 & 0.98 & 0.99 & 0.99 & 0.99 & 0.99 & 0.99 & 0.96 & 0.93 & 0.91 & 0.90 & 0.90 & 0.85 & 0.98 \\
\hline & Productivity & 0.00 & 0.66 & 0.90 & 0.96 & 0.98 & 0.98 & 0.98 & 0.99 & 0.99 & 0.98 & 0.99 & 0.96 & 0.97 & 0.96 & 0.95 & 0.94 & 0.98 & 0.97 \\
\hline & Coastal protection & 0.91 & 0.50 & 0.60 & 0.48 & 1.00 & 1.00 & 0.50 & 0.47 & 0.47 & 1.00 & 0.36 & 0.99 & 0.97 & 0.84 & 1.00 & 0.99 & 1.00 & 0.91 \\
\hline & Coastal pollution & 0.50 & 1.00 & 1.00 & 1.00 & 0.00 & 0.50 & 0.00 & 0.00 & 0.50 & 0.50 & 0.50 & 0.00 & 0.00 & 0.00 & 0.50 & 0.50 & 0.50 & 0.50 \\
\hline & Priority index & 0.80 & 0.80 & 0.80 & 0.60 & 0.60 & 0.60 & 0.60 & 0.60 & 0.60 & 0.60 & 1.60 & 1.00 & 1.20 & 0.20 & 0.20 & 0.60 & 0.40 & 0.60 \\
\hline
\end{tabular}


Appendix 6. Measuring stock status.

Following Kleisner et al. (2012), we assessed the stock status of the 10 main fish species caught by artisanal and industrial sectors per year. This calculation used the categories of exploitation that were most frequent over the last 10 years of the temporal series, such as developing, exploited, rebuilding, overexploited and collapsed. The score of the stock status variable ranged from 0 (least vulnerable) to 1 (most vulnerable), which we assigned points as follows: developing $=0$ points, exploited $=0.4$ points, rebuilding $=0.5$ points, overexploited $=0.8$ points, and collapsed $=1$ point

Table A6.1: Stock status assessment of the 10 fish species caught along the Brazilian coastline by artisanal and industrial sectors. *These were not identified at the species level, so we used the average value of the categories for the two more frequent species in that state.

\begin{tabular}{lllc}
\hline STATES & SPECIES & STOCK STATUS & SCORE \\
\hline AP & Sciades parkeri & overexploited & 0.8 \\
AP & Cynoscion acoupa & exploited & 0.4 \\
AP & Sciades couma & exploited & 0.4 \\
AP & Coryphaena hippurus & exploited & 0.4 \\
AP & Micropogonias furnieri & exploited & 0.4 \\
AP & Sciades proops & exploited & 0.4 \\
AP & Cynoscion virescens & overexploited & 0.8 \\
AP & Megalops atlanticus & rebuilding & 0.5 \\
AP & Bagre bagre & exploited & 0.4 \\
AP & Lutjanus purpureus & overexploited & 0.8 \\
\hline PA & Cynoscion acoupa & exploited & 0.4 \\
PA & Sciades parkeri & overexploited & 0.8 \\
PA & Scomberomorus brasiliensis & exploited & 0.4 \\
PA & Lutjanus purpureus & overexploited & 0.8 \\
PA & Sciades proops & exploited & 0.4 \\
PA & Cynoscion microlepidotus & exploited & 0.4 \\
PA & Sciades herzbergii & overexploited & 0.8 \\
PA & Macrodon ancylodon & exploited & 0.4 \\
PA & Coryphaena hippurus & exploited & 0.4 \\
PA & Sciades couma & exploited & 0.4 \\
\hline MA & Cynoscion acoupa & exploited & 0.4 \\
MA & Macrodon ancylodon & exploited & 0.4 \\
\hline & & &
\end{tabular}




\begin{tabular}{|c|c|c|c|}
\hline MA & Hexanematichthys herzbergii & overexploited & 0.8 \\
\hline MA & Scomberomorus brasiliensis & exploited & 0.4 \\
\hline MA & Aspistor quadriscutis & exploited & 0.4 \\
\hline MA & Micropogonias furnieri & exploited & 0.4 \\
\hline MA & Sciades proops & exploited & 0.4 \\
\hline MA & Bagre bagre & exploited & 0.4 \\
\hline MA & Cynoscion leiarchus & overexploited & 0.8 \\
\hline MA & Genyatremus luteus & overexploited & 0.8 \\
\hline PI & Lutjanus synagris & exploited & 0.4 \\
\hline $\mathrm{PI}$ & Scomberomorus brasiliensis & exploited & 0.4 \\
\hline $\mathrm{PI}$ & Scomberomorus cavalla & exploited & 0.4 \\
\hline PI & Euthynnus alletteratus & exploited & 0.4 \\
\hline PI & Ocyurus chrysurus & exploited & 0.4 \\
\hline PI & Lutjanus purpureus & overexploited & 0.8 \\
\hline $\mathrm{PI}$ & Micropogonias furnieri & exploited & 0.4 \\
\hline PI & Conodon nobilis & overexploited & 0.8 \\
\hline PI & Chloroscombrus chrysurus & exploited & 0.4 \\
\hline PI & Lycengraulis grossidens & exploited & 0.4 \\
\hline CE & Ocyurus chrysurus & exploited & 0.4 \\
\hline CE & Opisthonema oglinum & exploited & 0.4 \\
\hline CE & Scomberomorus cavalla & exploited & 0.4 \\
\hline CE & Lutjanus synagris & exploited & 0.4 \\
\hline CE & Scomberomorus brasiliensis & exploited & 0.4 \\
\hline CE & Haemulon plumierii & exploited & 0.4 \\
\hline CE & Chloroscombrus chrysurus & exploited & 0.4 \\
\hline CE & Carangoides bartholomaei & exploited & 0.4 \\
\hline CE & Mycteroperca bonaci & overexploited & 0.8 \\
\hline CE & Lutjanus purpureus & overexploited & 0.8 \\
\hline RN & Xiphias gladius & exploited & 0.4 \\
\hline $\mathrm{RN}$ & Thunnus albacares & exploited & 0.4 \\
\hline RN & Opisthonema oglinum & exploited & 0.4 \\
\hline RN & Hirundichthys affinis & overexploited & 0.8 \\
\hline RN & Thunnus obesus & overexploited & 0.8 \\
\hline RN & Scomberomorus brasiliensis & exploited & 0.4 \\
\hline RN & Prionace glauca & exploited & 0.4 \\
\hline RN & Xyrichtys novacula & overexploited & 0.8 \\
\hline RN & Haemulon plumierii & exploited & 0.4 \\
\hline $\mathrm{RN}$ & Ocyurus chrysurus & exploited & 0.4 \\
\hline PB & Thunnus albacares & exploited & 0.4 \\
\hline PB & Thunnus obesus & overexploited & 0.8 \\
\hline PB & Xiphias gladius & exploited & 0.4 \\
\hline PB & Thunnus alalunga & overexploited & 0.8 \\
\hline PB & Prionace glauca & exploited & 0.4 \\
\hline
\end{tabular}




\begin{tabular}{|c|c|c|c|}
\hline PB & Mugil curema & collapsed & 1 \\
\hline PB & Istiophorus platypterus & overexploited & 0.8 \\
\hline PB & Centropomus undecimalis & exploited & 0.4 \\
\hline PB & Trachinotus falcatus & overexploited & 0.8 \\
\hline PB & Scomberomorus brasiliensis & exploited & 0.4 \\
\hline $\mathrm{PE}$ & Anchovia clupeoides & exploited & 0.4 \\
\hline PE & Thunnus albacares & exploited & 0.4 \\
\hline PE & Pseudupeneus maculatus & exploited & 0.4 \\
\hline PE & Mugil curema & collapsed & 1 \\
\hline PE & Opisthonema oglinum & exploited & 0.4 \\
\hline PE & Haemulon aurolineatum & rebuilding & 0.5 \\
\hline PE & Conodon nobilis & overexploited & 0.8 \\
\hline PE & Sparisoma spp_axillare & exploited & 0.4 \\
\hline PE & Lutjanus analis & exploited & 0.4 \\
\hline $\mathrm{PE}$ & Acanthocybium solandri & rebuilding & 0.5 \\
\hline $\mathrm{AL}$ & Mugil curvidens & exploited & 0.4 \\
\hline $\mathrm{AL}$ & Opisthonema oglinum & exploited & 0.4 \\
\hline $\mathrm{AL}$ & Macrodon ancylodon & exploited & 0.4 \\
\hline $\mathrm{AL}$ & Caranx hippos & exploited & 0.4 \\
\hline $\mathrm{AL}$ & Diapterus auratus & exploited & 0.4 \\
\hline $\mathrm{AL}$ & Scomberomorus brasiliensis & exploited & 0.4 \\
\hline $\mathrm{AL}$ & Balistes vetula & rebuilding & 0.5 \\
\hline $\mathrm{AL}$ & Scomberomorus cavalla & exploited & 0.4 \\
\hline $\mathrm{AL}$ & Mugil liza & rebuilding & 0.5 \\
\hline$A L$ & Sciades herzbergii & overexploited & 0.8 \\
\hline SE & Mugil curema & collapsed & 1 \\
\hline SE & Macrodon ancylodon & exploited & 0.4 \\
\hline SE & Sciades herzbergii & overexploited & 0.8 \\
\hline SE & Anchoviella vaillanti & overexploited & 0.8 \\
\hline SE & Caranx hippos & exploited & 0.4 \\
\hline SE & Micropogonias furnieri & exploited & 0.4 \\
\hline SE & Diapterus rhombeus & overexploited & 0.8 \\
\hline SE & Cathorops spixii & overexploited & 0.8 \\
\hline SE & Scomberomorus cavalla & exploited & 0.4 \\
\hline SE & Conodon nobilis & overexploited & 0.8 \\
\hline BA & Sardinella brasiliensis & rebuilding & 0.5 \\
\hline BA & Ocyurus chrysurus & exploited & 0.4 \\
\hline BA & Opisthonema oglinum & exploited & 0.4 \\
\hline BA & Diapterus rhombeus & overexploited & 0.8 \\
\hline BA & Cetengraulis edentulus & rebuilding & 0.5 \\
\hline BA & Lutjanus jocu & exploited & 0.4 \\
\hline BA & Coryphaena hippurus & exploited & 0.4 \\
\hline BA & Mycteroperca spp_bonaci & overexploited & 0.8 \\
\hline
\end{tabular}




\begin{tabular}{|c|c|c|c|}
\hline BA & Caranx crysos & exploited & 0.4 \\
\hline BA & Pomacanthus paru & exploited & 0.4 \\
\hline ES & Coryphaena hippurus & exploited & 0.4 \\
\hline ES & Balistes capriscus & overexploited & 0.8 \\
\hline ES & Thunnus albacares & exploited & 0.4 \\
\hline ES & Ocyurus chrysurus & exploited & 0.4 \\
\hline ES & Trachurus lathami & rebuilding & 0.5 \\
\hline ES & Pagrus pagrus & rebuilding & 0.5 \\
\hline ES & Caranx crysos & exploited & 0.4 \\
\hline ES & Katsuwonus pelamis & exploited & 0.4 \\
\hline ES & Lutjanus purpureus & overexploited & 0.8 \\
\hline ES & Coryphaena hippurus & exploited & 0.4 \\
\hline RJ & Sardinella brasiliensis & rebuilding & 0.5 \\
\hline RJ & Cetengraulis edentulus & rebuilding & 0.5 \\
\hline RJ & Katsuwonus pelamis & exploited & 0.4 \\
\hline RJ & Stephanolepis hispidus & collapsed & 1 \\
\hline RJ & Scomber colias & collapsed & 1 \\
\hline RJ & Micropogonias furnieri & exploited & 0.4 \\
\hline RJ & Caranx latus & exploited & 0.4 \\
\hline RJ & Thunnus albacares & exploited & 0.4 \\
\hline RJ & Opisthonema oglinum & exploited & 0.4 \\
\hline RJ & Lophius gastrophysus & overexploited & 0.8 \\
\hline SP & Sardinella brasiliensis & rebuilding & 0.5 \\
\hline SP & Micropogonias furnieri & exploited & 0.4 \\
\hline SP & Cynoscion jamaicensis & overexploited & 0.8 \\
\hline SP & Anchoviella lepidentostole & exploited & 0.4 \\
\hline SP & Macrodon atricauda & overexploited & 0.8 \\
\hline SP & Scomber colias & collapsed & 1 \\
\hline SP & Lophius gastrophysus & overexploited & 0.8 \\
\hline SP & Xiphias gladius & exploited & 0.4 \\
\hline SP & Mugil liza & rebuilding & 0.5 \\
\hline SP & Coryphaena hippurus & exploited & 0.4 \\
\hline PR & Sardinella brasiliensis & rebuilding & 0.5 \\
\hline PR & Harengula clupeola & overexploited & 0.8 \\
\hline$P R$ & Chloroscombrus chrysurus & exploited & 0.4 \\
\hline$P R$ & Micropogonias furnieri & exploited & 0.4 \\
\hline$P R$ & Opisthonema oglinum & exploited & 0.4 \\
\hline PR & Cynoscion virescens & overexploited & 0.8 \\
\hline PR & Oligoplites spp_saurus_saliens* & collapsed/rebuilding & 0.75 \\
\hline PR & Pogonias cromis & collapsed & 1 \\
\hline PR & Macrodon atricauda & overexploited & 0.8 \\
\hline PR & Mugil liza & rebuilding & 0.5 \\
\hline SC & Sardinella brasiliensis & rebuilding & 0.5 \\
\hline
\end{tabular}




\begin{tabular}{llll} 
SC & Katsuwonus pelamis & exploited & 0.4 \\
SC & Micropogonias furnieri & exploited & 0.4 \\
SC & Opisthonema oglinum & exploited & 0.4 \\
SC & Umbrina canosai & exploited & 0.4 \\
SC & Prionotus punctatus & exploited & 0.4 \\
SC & Urophycis mystacea & exploited & 0.4 \\
SC & Cynoscion guatucupa & exploited & 0.4 \\
SC & Chloroscombrus chrysurus & exploited & 0.4 \\
SC & Mugil liza & rebuilding & 0.5 \\
\hline RS & Micropogonias furnieri & exploited & 0.4 \\
RS & Umbrina canosai & exploited & 0.4 \\
RS & Cynoscion guatucupa & exploited & 0.4 \\
RS & Katsuwonus pelamis & exploited & 0.4 \\
RS & Macrodon atricauda & overexploited & 0.8 \\
RS & Prionotus punctatus & exploited & 0.4 \\
RS & Pomatomus saltatrix & collapsed & 1 \\
RS & Mugil liza & rebuilding & 0.5 \\
RS & Urophycis brasiliensis & exploited & 0.4 \\
RS & Thunnus albacares & exploited & 0.4 \\
\hline
\end{tabular}

